\title{
РЕКОНСТРУКЦИЯ КОРЕННЫХ ИСТОЧНИКОВ РОССЫПНЫХ МЕСТОРОЖДЕНИЙ НИЖНЕ-МЯКИТСКОГО РУДНО-РОССЫПНОГО УЗЛА (Северо-Восток России) НА ОСНОВЕ ИЗУЧЕНИЯ ТИПОМОРФНЫХ ПРИЗНАКОВ РОССЫПНОГО ЗОЛОТА
}

\author{
И. С. Литвиненко, Л. А. Шилина \\ ФГБУН Северо-Восточный комплексный научно-исследовательский институт \\ им. Н. А. Шило ДВО РАН, г. Магадан \\ E-mail: litvinenko@neisri.ru, SolomenL@neisri.ru
}

\begin{abstract}
На основе детального изучения типоморфных свойств самородного золота шлиховых проб уточнены местоположение и формационная принадлежность коренных источников россыпных месторождений Нижне-Мякитского рудно-россыпного узла Верхне-Колымского региона Яно-Колымской золотоносной провинции. Определены минеральные типы коренных источников и их роль в образовании россыпей узла. По парагенетическим ассоциациям микровключений в самородном золоте россыпей установлено, что их коренными источниками являлись висмут-сульфотеллуридный с высокопробным (850-1000\%), сульфидно-сульфоарсенидный с умереннонизкопробным-среднепробным (700-850\%) и серебро-полисульфидный с низкопробным (350-700\%) золотом минеральные типы золото-редкометалльного оруденения. На основе данных о долевом участии геохимических типов самородного золота в россыпных месторождениях оценена роль различных минеральных типов оруденения в формировании конкретных россыпей. В целом по россыпным месторождениям узла золото примерно в равных пропорциях поступило из сульфидно-сульфоарсенидного и серебро-полисульфидного типов при подчиненной роли висмут-сульфотеллуридного типа оруденения. Общая зональность распространения оруденения выражается в развитии в южной и западной частях узла (в пределах гранитного штока и близ него) преимущественно висмут-сульфотеллуридного и сульфидно-сульфоарсенидного, а в северной и восточной - серебро-полисульфидного типа оруденения.
\end{abstract}

Ключевые слова: Северо-Восток России, рудно-россыпной узел, россыпи, коренные источники, типоморфизм золота, гранулометрия, морфология, внутренние структуры, микровключения, индикаторные признаки.

DOI: $10.34078 / 1814-0998-2020-1-30-46$

\section{ВВЕДЕНИЕ}

Нижне-Мякитский рудно-россыпной узел располагается в восточной части Верхне-Колымского региона (Центрально-Колымские золотоносные районы) Яно-Колымской золотоносной провинции. Активные поиски, разведка и эксплуатация россыпных месторождений в Верхне-Колымском регионе ведутся с середины 1930-х гг. К настоящему времени здесь выявлено около 1300 россыпных месторождений с отработанными запасами золота от первых килограммов до 210 т. Их общая протяженность составляет 3800 км.

В первые годы освоения территории из типоморфных свойств самородного золота в россыпях изучали его пробность и гранулометрический состав, которые были необходимы при

(С Литвиненко И. С., Шилина Л. А., 2020 подсчете запасов. В более позднее время по единичным пробам в отдельных россыпях проводили химический, а также спектральный анализы самородного золота. Первая крупная сводная работа по типоморфизму самородного золота Центрально-Колымских золотоносных районов выполнена Л. Н. Пляшкевич с соавторами в конце 1950-х гг. (Л. Н. Пляшкевич и др., 1959 г.). Затрагивались вопросы типоморфизма золота в сводных описаниях россыпей Центрально-Колымских золотоносных районов, составленных в конце 1950-х гг. коллективом геологов под руководством Н. А. Шило, и в его диссертации (Шило, 1963). Обобщение материалов по типоморфным признакам самородного золота россыпных месторождений ВерхнеКолымского региона проведено С. В. Яблоковой с соавторами при выполнении работы по сводному описанию россыпных месторождений Северо-Востока СССР в начале 1970-х гг. 
(П. О. Генкин и др., 1973 г.). Отмеченные работы, а также многочисленные более поздние исследования (Кистеров, 1983; Пыцкая, 1994; Позднякова, 2015; и др.) были направлены в первую очередь на изучение типоморфных признаков самородного золота крупных и уникальных россыпных месторождений. Изучение типоморфных признаков самородного золота большинства мелких и средних россыпей Верхне-Колымского региона еще ждет своего часа.

Россыпная золотоносность Нижне-Мякитского рудно-россыпного узла установлена в 1934 г. В настоящее время здесь выявлено и практически полностью отработано 6 мелких и средних россыпных месторождений (рис. 1). Выполненные в ходе разведочных и эксплуатационных работ исследования самородного золота касались определения его пробности и гранулометрического состава.

Специализированные тематические исследования самородного золота россыпных месторождений Нижне-Мякитского рудно-россыпного узла впервые проведены В. М. Кузнецовым в конце 1980-х гг. Из россыпных месторождений узла были отобраны единичные шлиховые пробы, в которых атомно-абсорбционным анализом определена пробность, а спектральным анализом-геохимический состав самородного золота. На основе этих материалов сделаны выводы об оловянно-серебряном формационном типе коренных источников россыпей руч. 14-я Верста, Плацдарм, р. Мякит; золото-серебряном - россыпи руч. Кункуй; золото-сульфидно-кварцевом и золото-серебряном - россыпи руч. Берентал (Кузнецов и др., 1990). В 2003 г. Н. Е. Саввой с соавторами изучено самородное золото в шлиховой пробе из верховьев руч. Плацдарм. Коренным источником россыпи предполагается оруденение, связанное с гранитоидами (Савва и др., 2003). В 2011 г. В. М. Кузнецовым с соавторами высказано мнение о формировании россыпей руч. 14-Верста и Берентал за счет позднемелового золото-серебряного оруденения рудопроявления Берентал (Кузнецов и др., 2011). Из этого же типа оруденения, по их представлениям, поступала основная масса золота в россыпь руч. Плацдарм.

Цель настоящей работы - уточнение количества, местоположения и формационной принадлежности рудных проявлений, послуживших коренными источниками россыпных месторождений Нижне-Мякитского рудно-россыпного узла.

\section{МЕТОДИКА РАБОТ}

Были детально исследованы типоморфные свойства самородного золота 159 шлиховых проб, отобранных в 2008-2012 гг. из отработанных россыпных месторождений по 69 точкам с шагом 0.5-1 км (от 5 до 19 по каждой россыпи) (см. рис. 1). По единичным штуфным, протолочным и шлиховым (из элювиальных развалов рудных тел) пробам изучены также типоморфные признаки самородного золота в известных рудных проявлениях.

Из шлиховых концентратов, полученных после промывки на лотке рыхлого материала из россыпных месторождений, элювиальных развалов рудных тел и протолочных проб, самородное золото извлекали под бинокуляром.

Комплекс лабораторных исследований штуфных проб включал:

дробление до 1.0 мм с отбором навески массой 150-200 г для растворения в кислотах;

обработку материала отквартованных навесок плавиковой кислотой до полного растворения силикатных минералов;

отбор из образовавшегося рудного концентрата самородного золота под бинокуляром;

обработку рудного концентрата азотной кислотой до полного растворения присутствующих в нем сульфидов;

отбор из полученного остатка самородного золота под бинокуляром.

Определение пробности золотин и состава в них микровключений минералов выполнено в монтированных аншлифах локальным микрорентгеноспектральным анализом на микрозон-

Puc. 1. Геологическая схема Нижне-Мякитского рудно-россыпного узла. Схема составлена на геологической основе (В. В. Бурзайкин, 1995 г.), с дополнениями и упрощениями: 1 - четвертичные аллювиальные отложения речных долин; 2 - триасовые терригенные и вулканогенно-терригенные отложения Балыгычанского поднятия Яно-Колымской складчатой системы; 3 - раннемеловые среднезернистые $(a)$ и мелкозернистые (б) биотитовые граниты Берентальского штока; 4 - разрывные нарушения; 5 - минерализованные зоны дробления с прожилково-жильным окварцеванием и вкрапленно-прожилковой рудной минерализацией; 6 - золоторудные проявления (1 - Фронт, 2 - Плацдарм, 3 - Берентал); 7 - контуры россыпей с очень богатыми (a), богатыми (б), относительно богатыми (в) и бедными (2) участками; 8 - средняя пробность (над чертой) и средняя крупность (под чертой) самородного золота в россыпях по разведочным данным; 9 - места отбора шлиховых проб и номера точек, в которых изучен химический состав самородного золота; 10 - место отбора шлиховой пробы, исследованной Н. Е. Саввой с совторами (2003); 11-17 - обозначения геологических структур на врезке: 11,12 Верхояно-Чукотская (11) и Корякско-Камчатская (12) складчатые области; 13 - Охотский (Ох) и Омолонский (Ом) срединные массивы; 14 - Омулевское (О) и Приколымское (П) поднятия; 15, 16 - Охотско-Чукотский (15) и Уяндино-Ясачненский (16) вулканогенные пояса; 17 - наложенные кайнозойские впадины; 18 - местоположение Нижне-Мякитского рудно-россыпного узла 

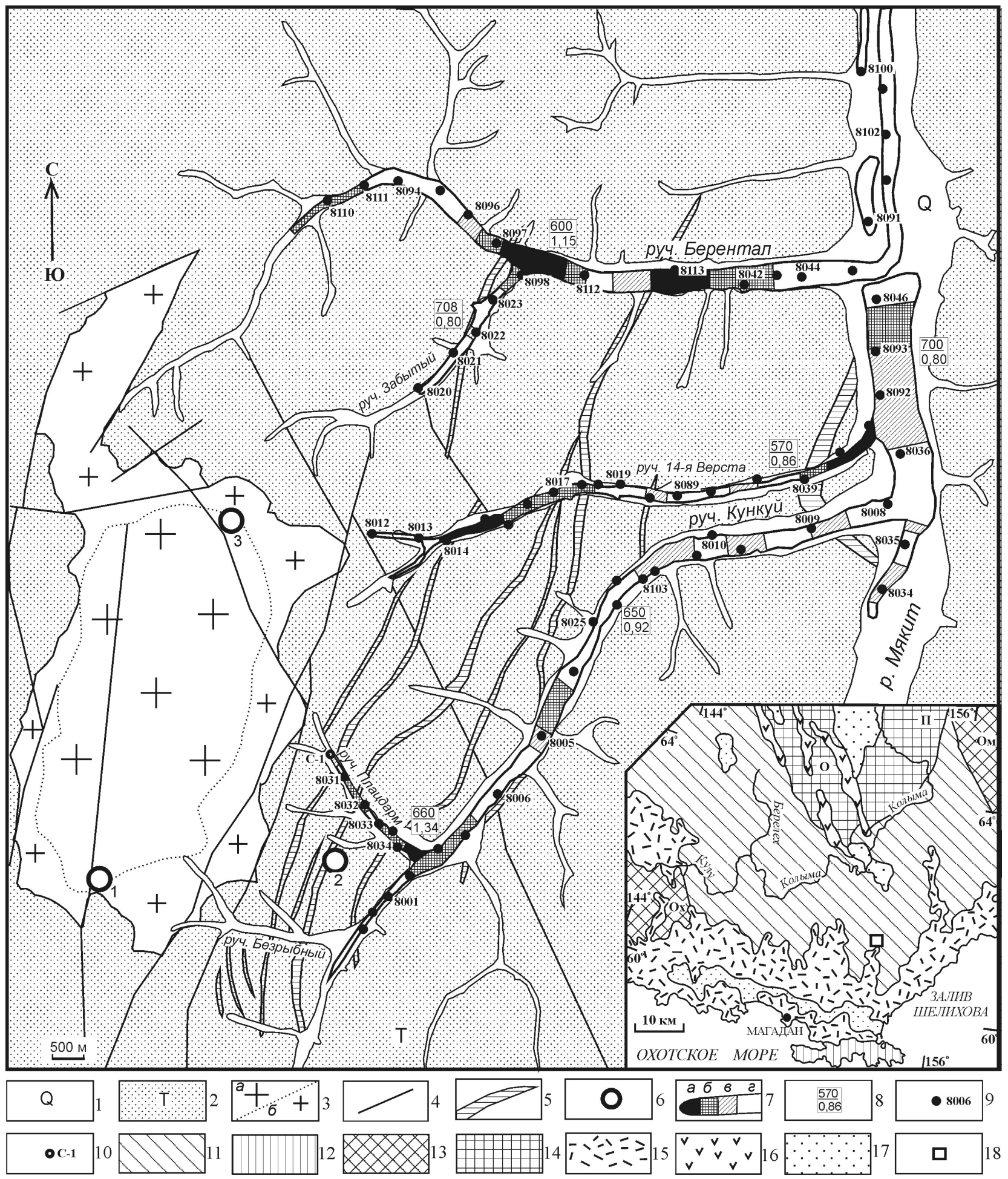

Fig. 1. Schematized geology of the Lower Myakit ore-placer knot based on V. V. Burzaykin (1995), amended and simplified: 1 - Quaternary alluvium in river valleys; 2 - Triassic terrigenous and volcanic-terrigenous rocks of the Balygychan uplift of the Yana-Kolyma folded system; 3 - Early Cretaceous medium-grained $(a)$ and fine-grained ( $\sigma$ ) biotite granite rocks of the Berental stock; 4 - fault structures; 5 - mineralized crush zones with vein-veinlet silification and impregnation-veinlet ore mineralization; 6 - gold ore occurrences ( 1 - Front, 2 - Platsdarm, 3 - Berental); 7 - contours of very rich (a), rich (6), relatively rich (b), and poor (2) placer areas; 8 - average fineness (above the line) and average size (below the line) of native gold in placers, according to geological prospecting data; 9 - heavy concentrate sampling sites and numbers of native gold chemical study sites; 10 - site of the heavy concentrate sample studied by N. E. Savva et al. (2003); 11-17 - geological structures on the inset: 11, 12 - Verkhoyansk-Chukotka (11) and Koryak-Kamchatka (12) folded areas; 13 - Okhotsk (Ox) and Omolon (OM) median massifs; 14 - Omulyovka (O) and Prikolymye (П) uplifts; 15, 16 - Okhotsk-Chukotka (15) and Uyandina-Yasachnaya (16) volcanic belts; 17 - superimposed Cenozoic depressions; 18 - Lower Myakit ore-placer knot 
довом анализаторе Camebax № 304, дополнительно укомплектованном энергодисперсионным спектрометром X-Max 50 английской фирмы Oxford Instruments, программное обеспечение Inca Energy (СВКНИИ ДВО РАН, г. Магадан, аналитики Т. В. Субботникова и Е. М. Горячева). Для изучения минерального состава микровключений в самородном золоте, кроме того, использовали сканирующий электронный микроскоп EVO-50 германской фирмы Carl Zeiss c рентгеновской системой энергодисперсионного микроанализа Quantax американской корпорации Bruker (СВКНИИ ДВО РАН, аналитики О. Т. Соцкая, Е. М. Горячева).

Геохимический состав зерен самородного золота из руд и россыпей определяли в монтированных аншлифах методом локального микрорентгеноспектрального анализа на анализаторе Camebax SX 1000 фирмы Cameca (ГЕОХИ РАН, г. Москва, аналитик Н. Н. Кононкова). Анализ выполняли на $\mathrm{Au}, \mathrm{Ag}, \mathrm{Cu}, \mathrm{Bi}, \mathrm{Pb}, \mathrm{Hg}, \mathrm{Sb}, \mathrm{Te}, \mathrm{Fe}$, $\mathrm{Zn}, \mathrm{Se}, \mathrm{As}$. Обработка результатов проведена с использованием пакета прикладных программ Leader* (Аналитический центр СВКНИИ ДВО РАН, оператор - ведущий инженер С. Г. Морозова).

Всего в ходе выполненных исследований описана морфология более 4100 зерен самородного золота. В монтированных аншлифах изучен состав 1066 золотин и 97 зерен, ассоциирующих с золотом минеральных образований. Определено содержание примесных элементов в 196 зернах самородного золота из двух рудных проявлений и шести россыпных месторождений (из верхней, средней и нижней их частей).

\section{ГЕОЛОГИЯ И ТИПОМОРФИЗМ САМОРОДНОГО ЗОЛОТА КОРЕННЫХ ПРОЯВЛЕНИЙ НИЖНЕ-МЯКИТСКОГО РУДНО-РОССЫПНОГО УЗЛА}

Нижне-Мякитский рудно-россыпной узел входит в состав Хурчан-Оротуканской золотоносной зоны на юго-восточном фланге Яно-Колымского золотоносного пояса. В тектоническом отношении он расположен в зоне юго-восточного замыкания Яно-Колымской складчатой системы Верхояно-Чукотской складчатой области вблизи ее границы с Охотско-Чукотским вулканогенным поясом (см. рис. 1).

Рудно-россыпной узел приурочен к Берентальскому штоку и восточному крылу одноименной интрузивно-купольной структуры (см. рис. 1). Берентальский шток сложен лейкократовыми гранитами, относящимися к меловой гранодиорит-гранитной ассоциации I типа (Goryachev, Goncharov, 1995). Возраст гранитов

*Разработка информационно-вычислительного центра ПГО «Севзапгеология».
$140 \pm 1$ млн лет (Ньюберри и др., 2000). На восточном крыле Берентальской структуры развиты раннетриасовые отложения, представленные глинистыми и песчано-глинистыми сланцами, алевролитами и аргиллитами с маломощными горизонтами песчаников.

В пределах Нижне-Мякитского рудно-россыпного узла установлено около 60 точек минерализации и мелких рудных проявлений. Типоморфные особенности самородного золота изучали на рудопроявлениях Фронт, Плацдарм и Берентал (см. рис. 1).

Рудопроявление Фронт располагается в южной части Берентальского штока и представлено пологозалегающей рудной зоной сульфидно-кварцевого прожилкования и березитизации. Помимо золота, в рудах отмечаются повышенные содержания серебра, мышьяка, висмута.

Богатая золоторудная минерализация связана с кварцевыми жилами и прожилками. В них выделяются две ассоциации рудных минералов: сульфидно-арсенидная и сульфотеллуридновисмутовая (Горячев, Колесниченко, 1990). Сульфидно-арсенидная ассоциация представлена арсенопиритом, леллингитом (с примесью самородного висмута и золота), пиритом, пирротином, сфалеритом. В составе сульфотеллуридно-висмутовой ассоциации выявлены висмутин, жозеит А и В, хедлейит, самородные золото и висмут (Там же). По последним данным (Соломенцева, Литвиненко, 2015), в ней преобладают сульфотеллуриды и сульфиды висмута, самородное золото и мальдонит. Золоторедкометалльное оруденение, распространенное на рудном проявлении Фронт, по классификации Н. А. Горячева и Г. Н. Гамянина (2006) относится к висмут-сульфотеллуридному минеральному типу.

В рудах преобладает весьма мелкое (0.1$0.25 \mathrm{Mм}$ ) и тонкое (менее $0.1 \mathrm{Mм)} \mathrm{золото} \mathrm{(Соло-}$ менцева, Литвиненко, 2015). Отмечаются две разновидности золотин: монолитные и пористые (ветвисто-пористые) с оксидами висмута. Монолитные золотины в количественном отношении преобладают и представляют собой гипогенные образования самородного золота, отложившиеся из рудоносных растворов. Пробность их колеблется от 866 до 1000\% с резким преобладанием зерен с пробностью 890-950\%. Золотины ветвисто-пористого строения присутствуют в подчиненном количестве. Сложены они золотом с пробностью около 1000\% и, вероятно, образовались в результате гипогенного разложения мальдонита.

Рудопроявление Плацдарм локализовано в триасовых терригенных породах на восточном крыле Берентальской интрузивно-купольной структуры (см. рис. 1). Потенциальные рудные тела представляют собой протяженные зоны смятия с элементами брекчирования пород, со- 
провождающиеся прожилково-жильным окварцеванием и вкрапленно-прожилковой сульфидизацией.

В исследованной авторами протолочной пробе из сульфидно-кварцевой жилы в днище долины руч. Плацдарм среди рудных минералов преобладает арсенопирит при подчиненной роли пирита и очень небольшом количестве сфалерита и самородного золота (Литвиненко, Шилина, 2017). В качестве микровключений в самородном золоте установлены серебро- и висмутсодержащий галенит (содержания Ві достигают 7.83 мас.\%), интерметаллид $\mathrm{Au}-\mathrm{Ag}-\mathrm{Pb}$, ютенбогаардтит, сульфоарсениды серебра (?). Размер 30лотин не превышает 1.0 мм. Преобладают зерна с пробностью 700-750 и 800-850\%о (средняя $799 \%$ ). В протолочной пробе из развитой здесь же серии сульфидно-кварцевых прожилков превалирует пирит, в значительно меньшем количестве присутствуют арсенопирит и халькопирит. Установлены два типа золота. Первый тип представлен зернами крупностью до 0.5 мм в сростках с сульфидами и кварцем. Пробность золотин колеблется от 727 до 900\%, средняя - 818\%о. В низкопробных золотинах выявлен ютенбогаардтит. Второй тип включает золотины в сростках с кварцем и породой. Крупность золотин достигает 2.0 мм, пробность колеблется от 670 до 788\%, средняя - 713\%. В качестве включений в низкопробном самородном золоте, помимо пирита и арсенопирита, установлены селенистый галенит, акантит, ютенбогаардтит, пирротин.

В опробованной авторами системе сульфидных прожилков на междуречье Плацдарм - Безрыбный мощность прожилков составляет до 3 5 см. Сложены они арсенопиритом. В нем в виде вкрапленности отмечаются халькопирит, сфалерит и ковеллин. Арсенопирит несет следы выщелачивания, разбит на отдельные слабо связанные между собой обломки, замещенные с поверхности оксидами и гидроксидами мышьяка и железа. Размер выделенных из штуфной пробы зерен золота менее 0.1 мм. Пробность их колеблется от 640 до 843\%о (при преобладании зерен с пробностью от 650 до 800\%о), средняя пробность составляет 724\%о. Около 20\% зерен находятся в сростках с «горчичным» золотом.

По минеральному составу охарактеризованное оруденение относится к сульфидносульфоарсенидному (по классификации Н. А. Горячева и Г. Н. Гамянина (2006) - висмутарсенидно-сульфоарсенидному) минеральному типу золото-редкометалльной формации.

В исследованной штуфной пробе из системы карбонатно-кварцевых прожилков на междуречье Безрыбный - Плацдарм масса рудных минералов составила около 10.0\% (Литвиненко, Шилина, 2017). В основном это арсенопирит, в единичных зернах - вольфрамит. Примерно в равных пропорциях выявлены зерна самородного золота и мальдонита (или его сростков с самородным 30лотом). Самородное золото представлено зернами менее 0.1 мм. Пробность золотин колеблется от 896 до 1000\%, средняя - 949\%о. По аналогии с рудопроявлением Фронт данное оруденение можно отнести к висмут-сульфотеллуридному минералого-геохимическому типу золоторедкометалльной формации.

Рудопроявление Берентал представлено зонами сульфидно-кварцевого прожилкования в березитизированных гранитах в северной части Берентальского штока. Рудная минерализация в кварцевых жилах и прожилках составляет 5-30\%. В протолочке из кварцевой жилы обнаружены магнетит и пирит, в небольшом количестве арсенопирит, галенит, сфалерит, акантит; в аншлифах - арсенопирит, пирит, галенит, кобеллит и галеновисмутит (Кузнецов и др., 2011). В отмеченной протолочной пробе выявлены единичные зерна самородного золота с пробностью 691\% (Кузнецов и др., 1990).

В шлиховой пробе, отобранной из окисленных руд в минерализованной тектонической зоне, в массовом отношении преобладают зерна класса 0.1-0.25 мм (Литвиненко, Шилина, 2018). По текстурному строению установлены две разновидности самородного золота: монолитное и микропористое.

Монолитное золото составляет 44.8\%. По пробности в нем выделяются четыре группы (генерации): весьма низкопробная (преобладает золото с пробностью 450-500\%о), низкопробная (преобладает золото с пробностью 600-650\%о), умереннонизкопробная (преобладает золото с пробностью 700-750\%о) и средне-высокопробная (преобладают зерна с пробностью 900-950\%о). Низкопробная, умереннонизкопробная и средневысокопробная группы золота присутствуют примерно в равных пропорциях (соответственно 24, 31 и 37\%), весьма низкопробная играет подчиненную роль (7\%). Средняя пробность золота $759 \%$.

На микропористые выделения, получившие в минералогическом обиходе название «горчичное» золото, приходится 55.2\%. Сложены такие зерна весьма высокопробным (около 1000\%о) самородным золотом.

По представлениям В. М. Кузнецова с соавторами (Кузнецов и др., 2011), на рудопроявлении Берентал имеет место совмещение золоторедкометалльной и ведущей более поздней золото-серебряной минерализации. По последним данным (П. А. Шерстобитов, 2017 г., 2018 г.; Литвиненко, Шилина, 2018), здесь развиты различные минеральные типы золоторедкометалльного оруденения.

В целом приведенные материалы по типоморфизму самородного золота в рудных проявлениях Нижне-Мякитского рудно-россыпного узла указывают на достаточно определенную 
специализацию самородного золота в исследованных минеральных типах развитого здесь золото-редкометалльного оруденения. Висмутсульфотеллуридный тип оруденения характеризуется высокопробным, а сульфидно-сульфоарсенидный - умереннонизкопробным-среднепробным самородным золотом.

\section{ГЕОЛОГИЯ РОССЫПНЫХ МЕСТОРОЖДЕНИЙ НИЖНЕ-МЯКИТСКОГО РУДНО-РОССЫПНОГО УЗЛА}

Нижне-Мякитский рудно-россыпной узел включает в себя россыпные месторождения p. Мякит и ее левых боковых притоков (см. рис. 1). Долины водотоков на участках залегания россыпей хорошо разработаны, корытообразной формы. Поверхность их коренного ложа как в поперечном, так и в продольном разрезе неровная, с многочисленными углублениями. Аллювий залегает на реликтах линейной коры химического выветривания (Шилина, Соцкая, 2018). У бортов он, как правило, перекрыт коллювиальными образованиями.

Россыпи представляют собой ленточные залежи, приуроченные преимущественно к днищам долин. Они состоят из серий богатых участков (по Н. А. Шило (1981), элементарных россыпей), соединяющихся между собой слабозолотоносными участками (см. рис. 1). Золотоносный пласт чаще всего располагается в реликтовых образованиях коры выветривания. Основная масса тяжелой фракции россыпей представлена оксидами и гидроксидами железа, гематитизированными и лимонитизированными обломками пород. В незначительном количестве отмечаются оксиды марганца, пирит, галенит (в том числе селенистый и мышьяковистый), сфалерит, молибденит, арсенопирит, касситерит, шеелит, вольфрамит, ильменит, халькопирит, антимонит, пирротин, халькозин, акантит, самородные золото, медь, серебро, висмут. Средняя крупность золота в россыпях варьирует от 0.86 до 1.34 мм. Доля неокатанных золотин по месторождениям составляет до $76 \%$. Генезис россыпей можно охарактеризовать как остаточноаллювиальный.

\section{ОПРЕДЕЛЕНИЕ МЕСТОПОЛОЖЕНИЯ И КОЛИЧЕСТВА КОРЕННЫХ ИСТОЧНИКОВ РОССЫПЕЙ}

Определение количества и местоположения коренных источников россыпных месторождений узла основывается на анализе изменения окатанности и морфологических характеристик самородного золота по простиранию россыпей.

Впервые на изменение морфологических характеристик и степени обработки зерен золота по простиранию россыпей обратил внимание Ю. А. Билибин (1938). Его теоретические разработки о закономерностях изменения морфологии и окатанности золота в россыпях впоследствии нашли подтверждение на конкретных объектах. Они легли в основу методических указаний (Костерин, 1972; Кистеров, Евсеев, 2001; и др.) по поиску золоторудных тел, послуживших коренными источниками россыпных месторождений.

Вполне очевидно, что морфологическая характеристика зерен самородного золота в россыпях и степень их обработки зависят от множества факторов (морфологических особенностей выделений самородного золота в исходном рудном материале, их крупности и т. д.). Но в целом общепринято считать, что вблизи коренного источника россыпь характеризуется наибольшей сферичностью и наименьшей окатанностью зерен самородного золота, ниже обработанность и уплощенность золотин возрастает. Хвостовые части россыпей сложены самородным золотом с наибольшей степенью окатанности и уплощенности. Если россыпное месторождение включает в себя серию элементарных россыпей, то отмеченная закономерность характерна для каждой из них.

Изучение морфологии самородного золота в россыпных месторождениях Нижне-Мякитского рудно-россыпного узла показало, что в россыпях руч. Плацдарм и Забытый отмечаются по два участка максимального (до 100\%) проявления неокатанного золота (в верхней и в нижней части россыпи), причем наиболее обширный участок расположен в нижней части. В россыпях руч. Кункуй и 14-я Верста таких участков 5 (на всем их протяжении), в россыпях руч. Берентал и р. Мякит - 3. Участки с максимальным (до 95\%) присутствием неокатанных разностей золота в россыпи руч. Берентал приурочены к средней и нижней ее части, в россыпи р. Мякит - к верхней и средней (рис. 2, a).

Анализ распределения комковидных разностей золота в россыпных месторождениях показал, что в россыпях руч. Берентал, Кункуй и р. Мякит отмечаются по 3 участка их максимального развития, в россыпи руч. 14-я Верста - 6 . Причем в россыпях руч. Берентал, 14-я Верста и p. Мякит такие участки наблюдаются и в их нижних частях. В россыпях руч. Плацдарм и Забытый комковидные образования самородного золота в повышенном количестве присутствуют в их средней и нижней частях (рис. 2, б).

В целом отмеченные особенности распространения неокатанных и комковидных разностей самородного золота в рассматриваемых россыпных месторождениях указывают на то, что россыпи формировались за счет многочисленных коренных источников, расположенных на всем их протяжении. Это подтверждается скачкообразным (многопиковым) характером распределения линейных запасов золота в россыпях, отмечающимся на всем их протяжении (Шилина, Соцкая, 2018). 


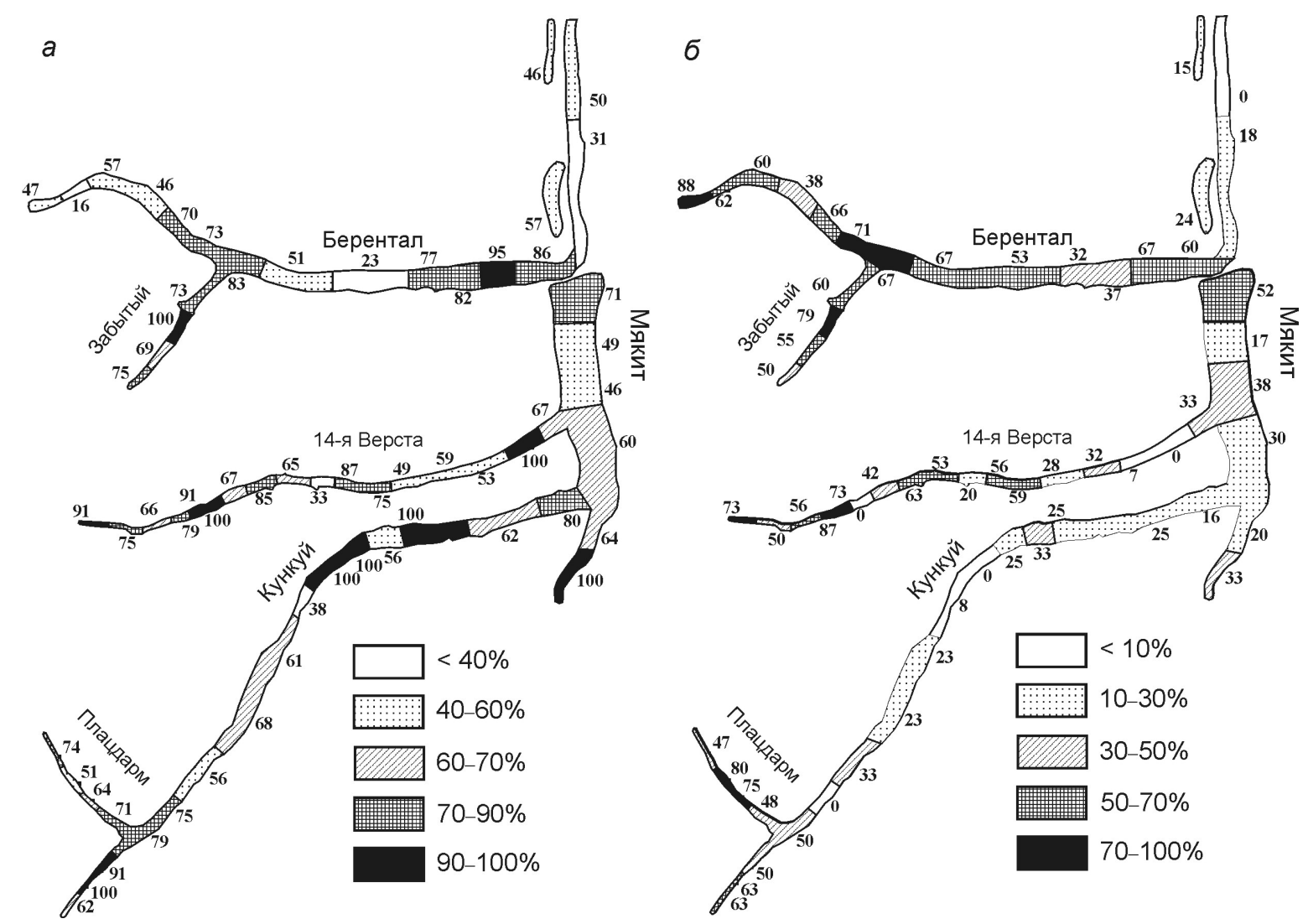

Puc. 2. Схема распространения неокатанного (a) и комковидного (б) золота в россыпях Нижне-Мякитского рудно-россыпного узла. Данные по золоту крупнее 0.25 мм. В надписях возле россыпей указано количество неокатанного $(a)$ и комковидного (б) самородного золота в точках опробования

Fig. 2. Schematized distribution of unrounded $(a)$ and lumpy (б) gold in the Lower Myakit placers. Data on gold larger than $0.25 \mathrm{~mm}$. The inscriptions at placer locations show amounts of unrounded $(a)$ and lumpy $(\sigma)$ varieties of native gold at sampling sites

\section{РЕКОНСТРУКЦИЯ ФОРМАЦИОННОЙ ПРИНАДЛЕЖНОСТИ КОРЕННЫХ ИСТОЧНИКОВ РОССЫПЕЙ}

Основная масса присутствующего в россыпях металла имеет гипогенный генезис. По пробности достаточно определенно выделяются четыре группы золота: весьма низкопробная (350-500\%о), низкопробная (500-700\%), умереннонизкопробнаясреднепробная (700-850\%) и высокопробная (850-1000\%o). Границы групп в различных россыпях на различных их участках могут смещаться на 50 (100)\% (рис. 3). Весьма низкопробное и низкопробное золото зачастую составляют одну группу (см. рис. 3).

Весьма низкопробная группа самородного золота наиболее распространена в россыпях руч. 14-я Верста и Берентал. Она представлена преимущественно мелкими (менее 1 мм) выделениями комковидно-уплощенной и комковидногнездовой формы с остроугольно-угловатыми, реже ксеноморфными и кристалломорфными очертаниями, массивной, реже блоковой и агрегатной текстурой и бугорчато-ямчатой поверхностью*.

*Характеристика морфологических и текстурных особенностей выделений самородного золота дана со-
По составу выделяются две подгруппы весьма низкопробного золота: высокосеребристая, в которой максимально распространены золотины с пробностью 400-450\%, и серебристая, в которой преобладают зерна с пробностью $500-550 \%$ (см. рис. 3).

Высокосеребристые золотины характеризуются монозернистой, зональной, коллоидной и колломорфно-зональной структурой. Состав таких зерен, за редким исключением, очень изменчивый. В зональных золотинах их краевые части имеют более серебристый состав (Соломенцева, Литвиненко, 2012). Иногда высокосеребристое золото отмечается совместно с серебристым золотом в комбинированных зернах (в виде отдельных блоков, цементирующего материала, наростов, каемок, прожилков и т. д.).

Выделения серебристой подгруппы весьма низкопробного самородного золота обычно имеют монозернистое и неяснозональное строение, реже зональность их строения проявляется достаточно отчетливо с уменьшением содержания серебра от краевых частей зерен к центральным.

гласно их систематикам и классификациям, приведенным в работе (Atlas..., 2007). 


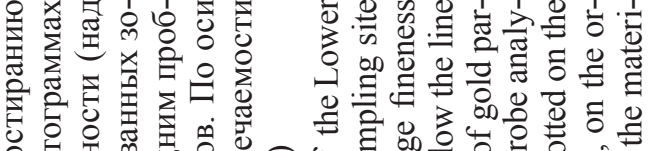

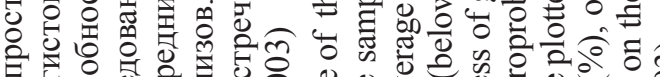

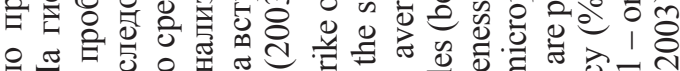

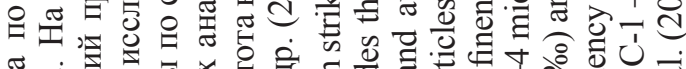

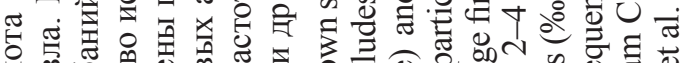

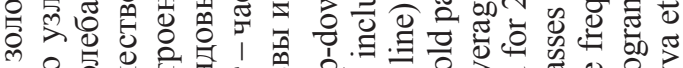

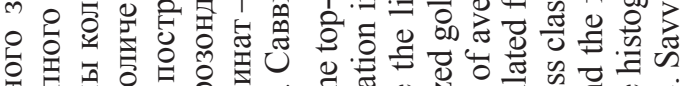

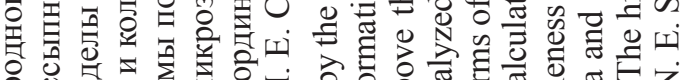

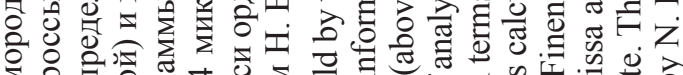

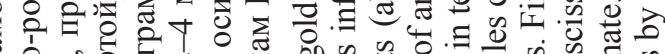
ฮ่

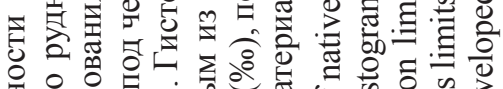

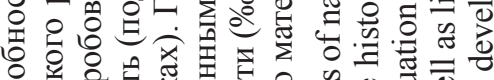

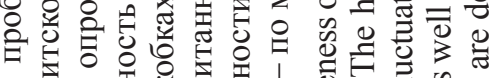

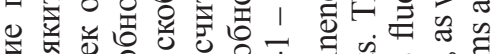

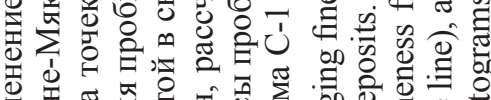

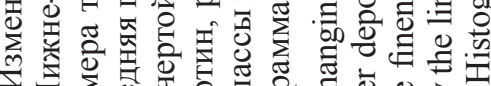

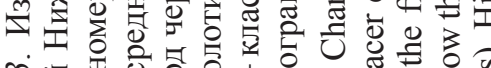
ri

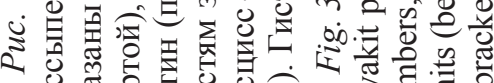

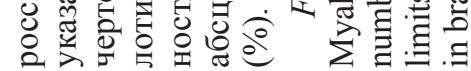
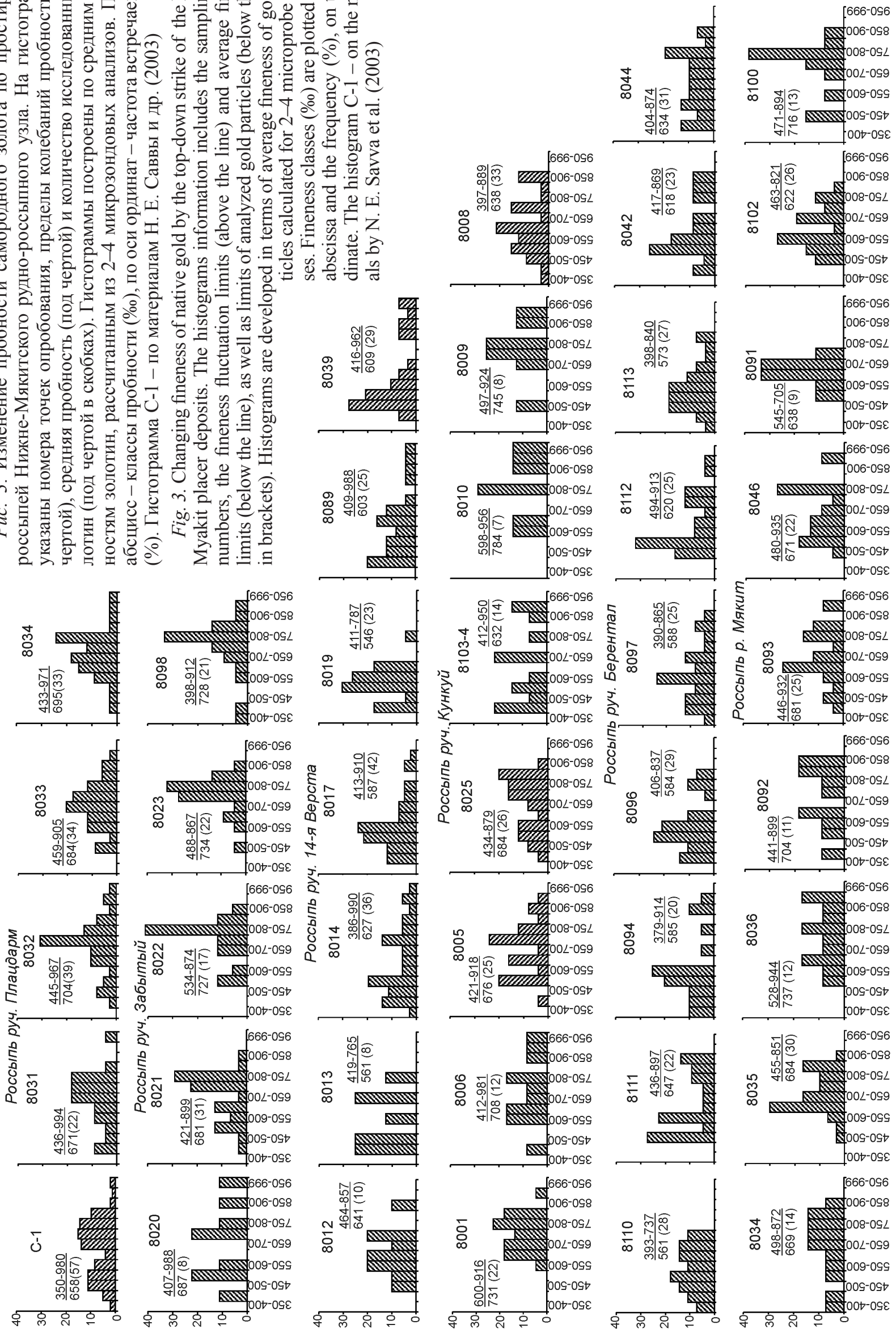
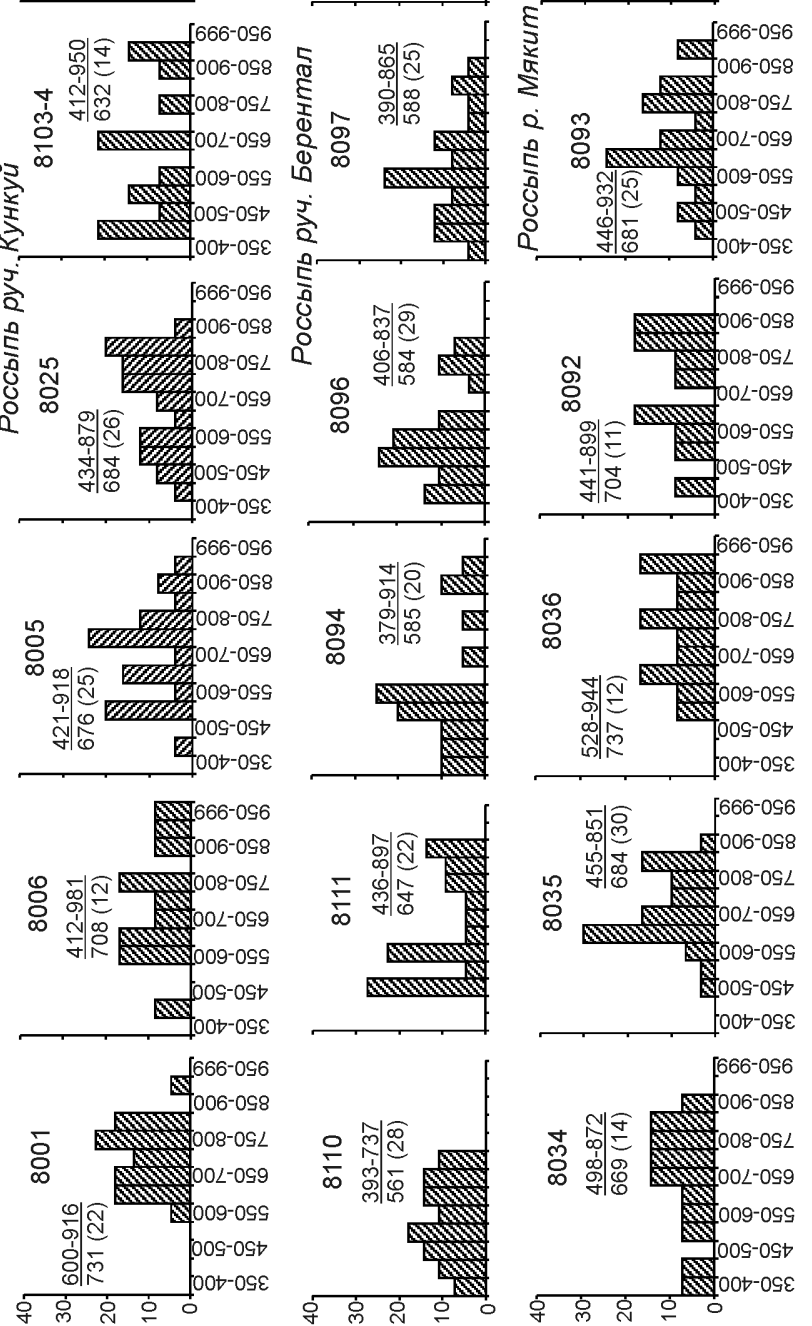
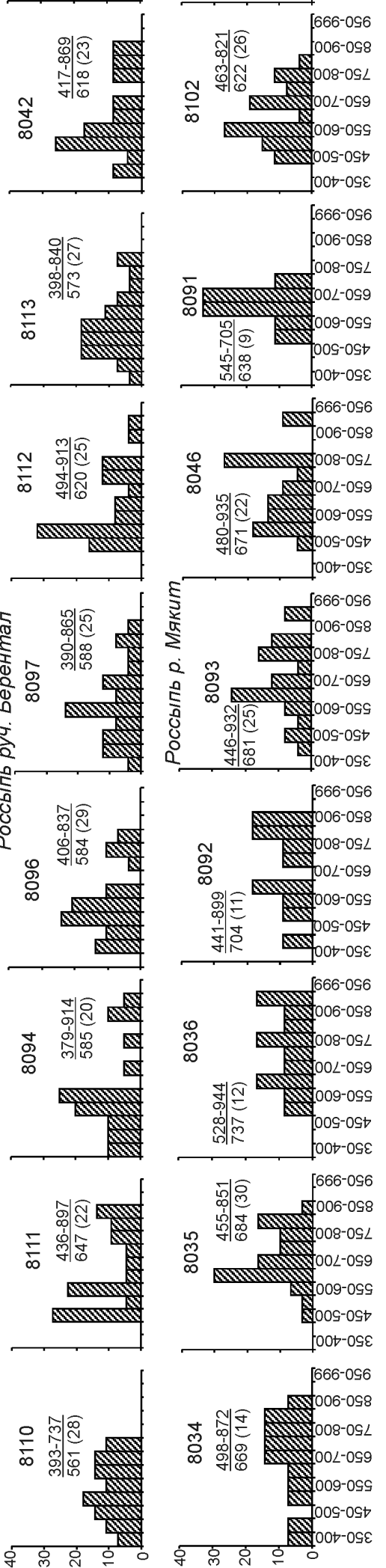
Отдельные золотины несут следы начальной грануляции. Зачастую границы зерен подчеркиваются более низкопробной фазой.

Низкопробная группа самородного золота наиболее распространена в россыпях руч. 14-я Верста, Берентал и р. Мякит. Она также представлена мелкими комковидно-гнездовыми и прожилковопластинчатыми остроугольно-угловатыми выделениями с массивной, реже блоковой, текстурой и бугорчато-ямчатой поверхностью. Они характеризуются монозернистой неяснозональной, реже зональной структурой с возрастанием содержания серебра к периферийным частям зерен. В некоторых золотинах отмечаются начальные стадии грануляции. Схожесть внутреннего строения золота низкопробной и весьма низкопробной групп указывает на идентичность условий его формирования.

Умереннонизкопробная-среднепробная группа самородного золота составляет основную массу металла россыпных месторождений руч. Кункуй, Плацдарм и Забытый. Среди выделений этой группы преобладают мелкие, реже среднего (1-2 мм) размера, образования комковидно-уплощенной и комковидной формы с остроугольно-угловатыми и ксеноморфными очертаниями, преимущественно массивной текстурой и бугорчато-ямчатой поверхностью. Они характеризуются в основном монозернистым строением. Изредка отмечаются золотины с неяснозональной и полизернистой структурой.

Высокопробная группа гипогенного золота наиболее распространена в верхней и нижней частях россыпи руч. Кункуй и в средней части россыпи р. Мякит. Она представлена золотинами мелкой и средней размерности, преимущественно комковидно-уплощенной формы с остроугольно-угловатыми очертаниями, массивной текстурой и бугорчато-ямчатой поверхностью. Состав их, как правило, достаточно однородный. Внутренняя структура характеризуется моно- или полизернистым строением.

Разнопробные группы самородного золота присутствуют в исследованных россыпях в раз- личных пропорциях. Их парагенетические ассоциации (табл. 1) указывают на поступление золота из рудных проявлений различных минеральных типов, формировавшихся в ходе развития единой золото-редкометалльной рудномагматической системы.

По парагенетическим ассоциациям микровключений (с учетом типоморфных признаков самородного золота в охарактеризованных рудных проявлениях) устанавливается достаточно определенная связь отмеченных разнопробных групп самородного золота с минеральными типами оруденения.

Высокопробная группа самородного золота является типоморфной для висмут-сульфотеллуридного типа руд. Выделения самородного золота умереннонизкопробной-среднепробной группы характерны для сульфидно-сульфоарсенидного типа оруденения.

Весьма низкопробная и низкопробная группы, как уже говорилось, на гистограммах пробности зачастую выделяются как одна группа (см. рис. 3), а входящие в них золотины имеют схожее внутреннее строение. Являющиеся типоморфными для весьма низкопробного золота микровключения акантита и ютенбогаардтита (см. табл. 1) на рудопроявлении Плацдарм отмечались и в низкопробных золотинах. Поэтому весьма низкопробную и низкопробную группы самородного золота мы склонны рассматривать как одну группу (низкопробную).

Впервые низкопробная группа (генерация) самородного золота была выделена Н. Е. Саввой с соавторами (2003) в шлиховой пробе, отобранной в верховьях руч. Плацдарм, и отнесена к более поздней стадии развития единого золоторедкометалльного коренного источника. В последующей публикации эта генерация связывается с проявлением позднемелового золотосеребряного оруденения (Кузнецов и др., 2011).

Ассоциация микровключений рудных минералов в низкопробных золотинах (см. табл. 1) отвечает золото-кварц-серебро-полисульфидному парагенезису месторождений золото-редкоме-

Таблица 1. Минеральный состав микровключений в гипогенном самородном золоте из россыпных месторождений, \%

Table 1. Mineral composition of microinclusions in hypogenous native gold from placer deposits, $\%$

\begin{tabular}{|c|c|c|c|c|c|c|c|c|c|c|c|c|c|c|c|c|c|c|}
\hline \multirow{2}{*}{$\begin{array}{c}\text { Группа } \\
\text { золота по } \\
\text { пробности, } \\
\text { \%о }\end{array}$} & \multirow{2}{*}{ 志 } & \multirow{2}{*}{ 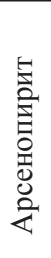 } & \multirow{2}{*}{ 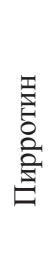 } & \multirow{2}{*}{ 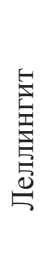 } & \multirow{2}{*}{ 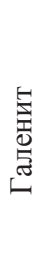 } & \multirow{2}{*}{ 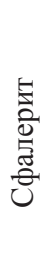 } & \multirow{2}{*}{ 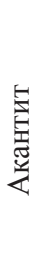 } & \multirow{2}{*}{ 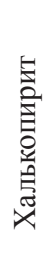 } & \multirow{2}{*}{ 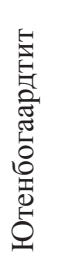 } & \multirow{2}{*}{ 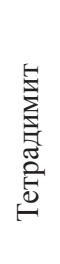 } & \multirow{2}{*}{ 离 } & \multicolumn{3}{|c|}{ Самородные } & \multicolumn{2}{|c|}{$\begin{array}{c}\text { Сульфо- } \\
\text { теллуриды }\end{array}$} & \multicolumn{2}{|c|}{$\begin{array}{c}\text { Висмуто- } \\
\text { вые сульфо- } \\
\text { соли }\end{array}$} \\
\hline & & & & & & & & & & & & $\mathrm{Bi}$ & $\mathrm{Pb}$ & $\mathrm{Sb}$ & $\mathrm{Bi}$ & $\mathrm{Ag}$ & $\mathrm{Pb}$ & $\mathrm{Pb}-\mathrm{Ag}$ \\
\hline $350-500$ & 6 & 6 & 13 & - & 38 & 6 & 6 & - & 6 & - & - & 6 & 6 & - & - & - & 6 & - \\
\hline $500-700$ & - & 18 & 9 & - & 45 & - & - & - & - & - & 9 & 10 & - & 9 & - & - & - & - \\
\hline $700-850$ & 8 & 17 & - & 8 & 17 & - & - & 8 & - & - & 8 & 17 & - & - & - & 8 & - & 8 \\
\hline $850-1000$ & 17 & - & - & - & - & - & - & - & - & 17 & 17 & 33 & - & - & 17 & - & - & - \\
\hline
\end{tabular}

Примечание. Прочерк - минерал не обнаружен. 
талльной формации (Палымский, 2012). Наличие наряду с акантитом и ютенбогаардтитом микровключений висмутовых минералов, играющих роль «минералогической подписи», позволяют, на наш взгляд, связать низкопробную группу самородного золота с развитием сереброполисульфидного минерального типа золоторедкометалльного оруденения. Являющиеся для нее типоморфными сульфидные минералы золота и серебра в ассоциации с весьма низкопробным и низкопробным самородным золотом распространены в золото-редкометалльных месторождениях Верхояно-Колымских мезозоид (Шило и др., 1988; Альшевский, 2011; и др.). Согласно модели рудно-магматической системы, связанной с интрузивами гранитоидов (Hart et al., 2002; Hart, 2005, 2007), они характерны для зоны с Ag-Pb-Zn «стилем» минерализации.

Таким образом, коренными источниками россыпных месторождений Нижне-Мякитского рудно-россыпного узла являлись серебро-полисульфидный с низкопробным, сульфидно-сульфоарсенидный с умереннонизкопробным-среднепробным и висмут-сульфотеллуридный с высокопробным золотом минеральные типы золото-редкометалльного оруденения. Долевое участие низкопробной, умереннонизкопробнойсреднепробной и высокопробной групп самородного золота в россыпных месторождениях узла позволяет оценить роль различных минеральных типов оруденения в формировании рассматриваемых россыпных месторождений.

В целом суммарное соотношение частоты встречаемости низкопробной, умереннонизкопробной-среднепробной и высокопробной групп самородного золота по россыпным месторождениям (рис. 4) указывает на ведущую роль в формировании россыпей руч. Берентал, 14-я Верста и р. Мякит сереброполисульфидного, а в образовании россыпей руч. Плацдарм и Забытый - сульфидно-сульфоарсенидного типов оруденения. В россыпь руч. Кункуй золото примерно в равных пропорциях поступило из серебро-полисульфидного и сульфидно-сульфоарсенидного типов руд.

По простиранию россыпных месторождений количество золота низкопробной, умереннонизкопробной-среднепробной и высокопробной групп очень сильно колеблется (рис. 5). Это указывает на различную роль минеральных типов золото-редкометалльного оруденения в формировании конкретных участков россыпных месторождений. Общая зональность золото-редкометалльного оруденения НижнеМякитского рудно-россыпного узла выражается в развитии в южной и западной частях узла преимущественно висмут-сульфотеллуридного и сульфидно-сульфоарсенидного, а в северной и восточной - серебро-полисульфидного типов оруденения.
Одним из важнейших показателей типоморфных свойств самородного золота, отражающим минералого-геохимическу обстановку рудообразования (тип минерализации), является его геохимический состав.

Комбинированными методами кластер-анализа по комплексу элементов-примесей с учетом их индикаторной роли проведена типизация самородного золота. В результате выделено 7 его геохимических типов. Состав самородного золота различных геохимических типов приведен в табл. 2.

Для более наглядного отражения геохимической специализации самородного золота различных геохимических типов выполнен расчет их «геохимических паспортов». В основу расчетов «геохимических паспортов» положено определение показателя «нормированное отклонение содержания элементов в данной выборке» $(\Delta)$. Его рассчитывали по формуле $\Delta=\left(\mathrm{X}_{\mathrm{i}}-\mathrm{X}_{\mathrm{o}}\right) / \sigma$, где $\mathrm{X}_{\mathrm{i}}$ и $\mathrm{X}_{\mathrm{o}}$ - соответственно средние значения логарифмов концентраций элемента в данной выборке и остальной части проб, $\sigma$ - стандартное отклонение логарифмов концентраций элемента во всей совокупности анализов. По значениям этого показателя оценивается индикаторная роль элементов в рассматриваемых выборках геохимических характеристик. Чем он больше, тем более высока индикаторная роль элемента в данной выборке, и наоборот.

Характеристика геохимических типов самородного золота по индикаторной роли элементовпримесей приведена на рис. 6.

Кроме 1-го геохимического типа самородного золота, характеризующегося очень высокой пробностью (более 981\%), пониженным содержанием $\mathrm{Hg}$ и $\mathrm{Cu}$, отсутствием As и спорадическим присутствием других элементов-примесей, в остальных типах определяющую положительную индикаторную роль играют следующие группы элементов: в самородном золоте 2-го геохимического типа - Fe, $\mathrm{Sb}, \mathrm{As}$; 3-го - $\mathrm{Bi}, \mathrm{Pb}$ и $\mathrm{As}$; 4-го - Bi, $\mathrm{Pb}$ и Hg; 5-го - Hg, Fe, $\mathrm{Zn}$ и Те; 6-го - Pb, As и $\mathrm{Fe} ; 7$-го - Sb, Ag и Tе.

Первый, 2-й, 3-й и 6-й геохимические типы самородного золота имеют локальное распространение и составляют единичные проценты от общего количества анализов. Основная масса 3олота представлена 4-м, 5-м и 7-м геохимическими типами (соответственно 21, 33 и 32\%).

Отмеченная связь высокопробной, умереннонизкопробной-среднепробной и низкопробной групп самородного золота в россыпях соответственно с висмут-сульфотеллуридным, сульфидно-арсенидным и серебро-полисульфидным типами золото-редкометалльной минерализации позволяет рассматривать их геохимическую характеристику как типоморфную для самородного золота минеральных типов присутствующего в Нижне-Мякитском рудно-россыпном узле золоторедкометалльного оруденения. 

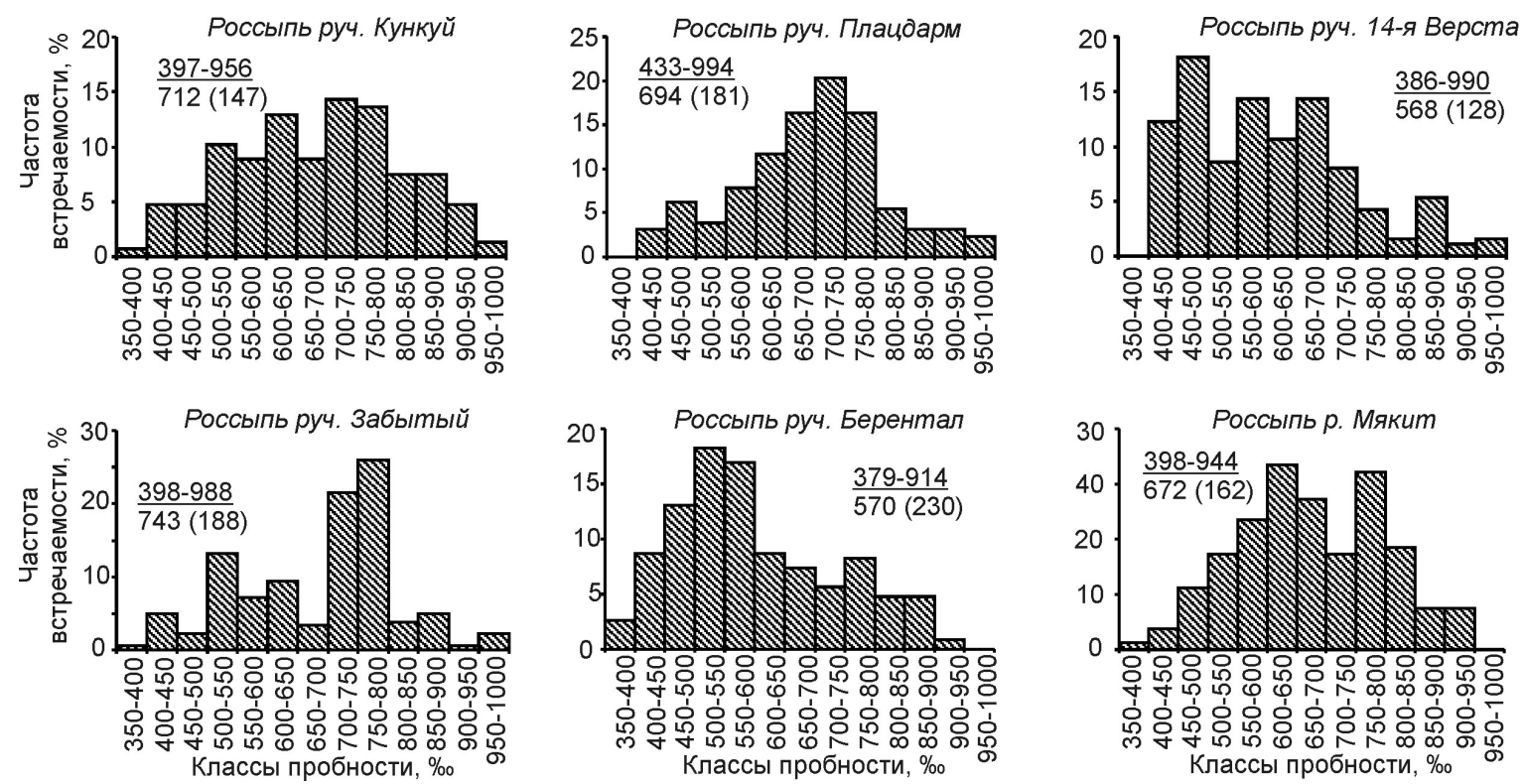

Puc. 4. Суммарная пробность самородного золота в россыпных месторождениях Нижне-Мякитского руднороссыпного узла. Над чертой - пределы колебаний пробности, под чертой - средняя пробность, в скобках - количество исследованных золотин. Гистограммы построены по средним пробностям золотин, рассчитанным как среднее арифметическое из 2-4 микрозондовых анализов

Fig. 4. Summarized native gold fineness in placer deposits of the Lower Myakit ore-placer knot. The fineness limits are indicated above the line, and average limits (below line), and the number of analyzed gold particles (in brackets). Histograms are developed in terms of average fineness of gold particles calculated as the arithmetic mean for 24 microprobe analyses

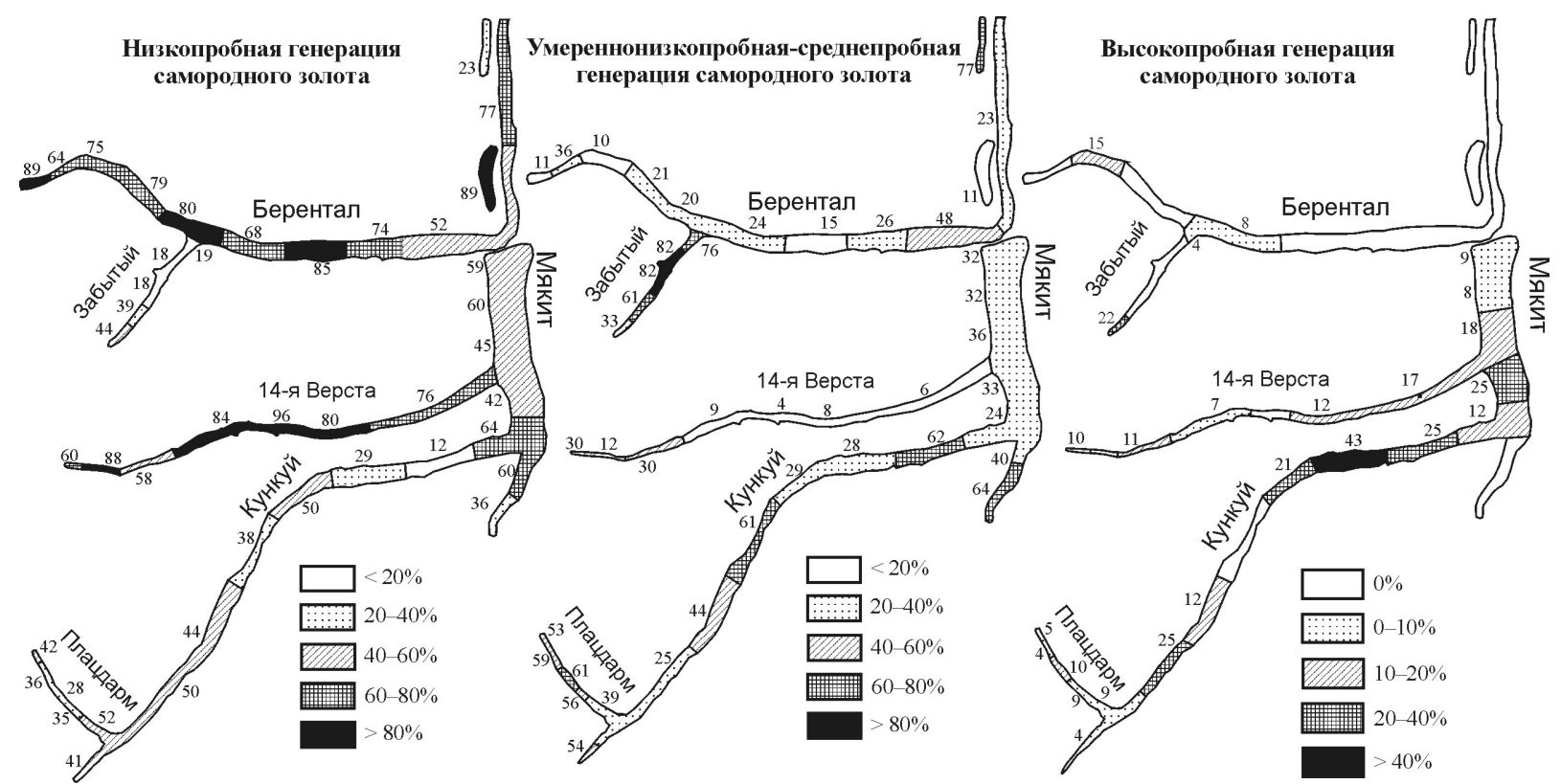

Pис. 5. Схема распределения разнопробных генераций самородного золота в россыпных месторождениях Нижне-Мякитского рудно-россыпного узла (в надписях возле россыпей указана доля разнопробных генераций самородного золота в точках опробования)

Fig. 5. Schematized distribution of native gold of different fineness in the Lower Myakit ore-placer knot (inscriptions at placers show shares of native gold generations of different fineness at sampling points)

Геохимическая специализация разнопробных генераций самородного золота подчеркивается различным долевым участием в составе разнопробных групп самородного золота его геохимических типов (табл. 3). Индикаторная роль гео- химических типов золота выражена в показателе (k) - средневзвешенной доли зерен золота данного геохимического типа в данной группе самородного золота (формула расчета приведена в табл. 3). Чем он выше, тем большую индика- 
Таблица 2. Средние содержания элементов в самородном золоте различных геохимических типов, мас. \% Table 2. Average element contents in native gold of different geochemichal types, mass. \%

\begin{tabular}{|l|c|c|c|c|c|c|c|}
\hline \multirow{2}{*}{ Элемент } & \multicolumn{7}{|c|}{ Геохимический тип самородного золота } \\
\cline { 2 - 8 } & 1 -й (3) & 2 -й (12) & 3-й (3) & 4 -й (41) & 5-й (64) & 6-й (11) & 7-й (63) \\
\hline $\mathrm{Au}$ & 98.457 & 66.975 & 69.100 & 78.470 & 65.132 & 62.421 & 60.953 \\
\hline $\mathrm{Ag}$ & 0.650 & 32.557 & 29.870 & 20.755 & 33.872 & 36.572 & 38.450 \\
\hline $\mathrm{Fe}$ & - & 0.052 & 0.030 & 0.031 & 0.039 & 0.540 & 0.022 \\
\hline $\mathrm{Hg}$ & 0.273 & 0.214 & 0.337 & 0.335 & 0.383 & 0.319 & 0.134 \\
\hline $\mathrm{Cu}$ & 0.043 & 0.054 & - & 0.051 & 0.045 & 0.058 & 0.052 \\
\hline $\mathrm{Bi}$ & - & 0.022 & 0.243 & 0.129 & 0.064 & 0.043 & 0.084 \\
\hline $\mathrm{As}$ & - & 0.075 & 0.120 & 0.041 & 0.048 & 0.099 & 0.052 \\
\hline $\mathrm{Pb}$ & - & - & 0.173 & 0.096 & 0.042 & 0.145 & 0.032 \\
\hline $\mathrm{Zn}$ & - & - & - & 0.035 & 0.038 & 0.023 & 0.033 \\
\hline $\mathrm{Sb}$ & - & 0.110 & - & 0.034 & 0.055 & 0.054 & 0.104 \\
\hline $\mathrm{Te}$ & - & 0.117 & 0.103 & 0.073 & 0.142 & 0.152 & 0.162 \\
\hline $\mathrm{Se}$ & - & 0.022 & - & 0.032 & 0.032 & 0.032 & 0.031 \\
\hline
\end{tabular}

Примечание. В скобках - количество анализов. Прочерк - элемент не обнаружен.

$\Delta$

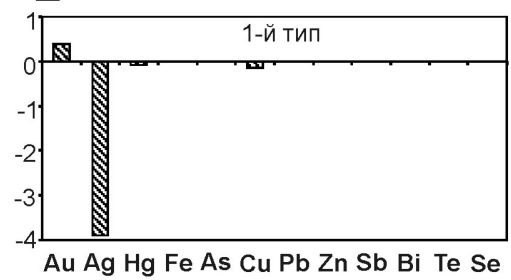

$\Delta$

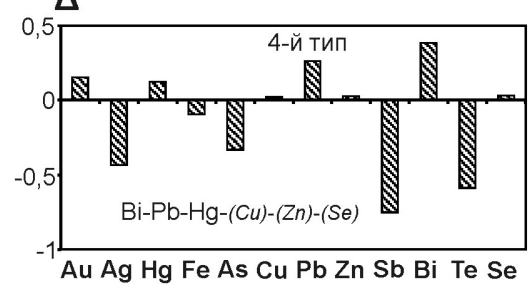

$\Delta$

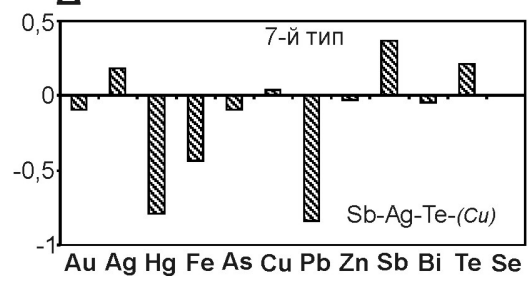

$\Delta$

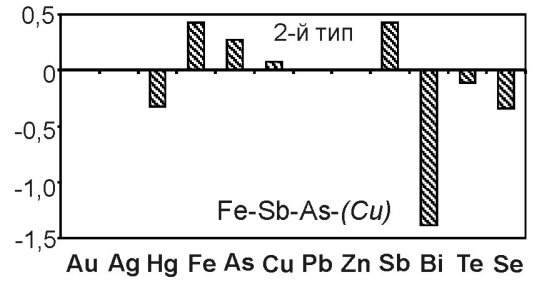

$\Delta$

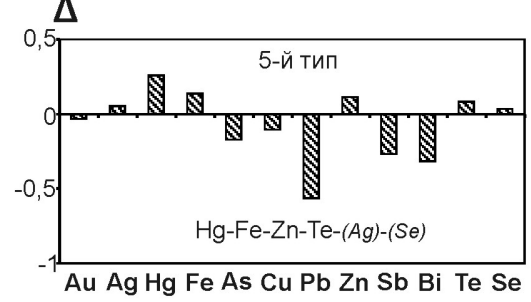

$\Delta$

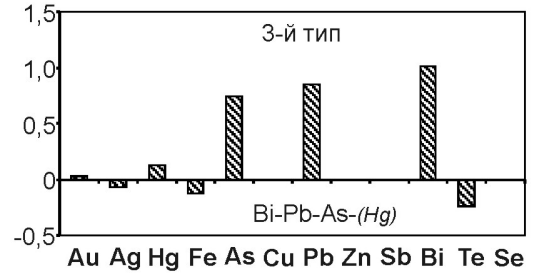

$\Delta$

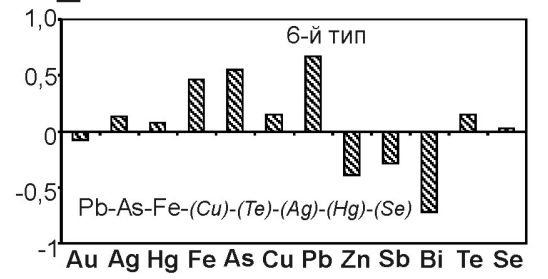

Puc. 6. «Геохимические паспорта» типов самородного золота. $\Delta-$ нормированное отклонение содержания элементов в самородном золоте (в надписях на диаграммах указаны элементы-примеси, играющие положительную индикаторную роль, расположенные в порядке убывания их значимости. В скобках - элементы-примеси с низкой индикаторной ролью)

Fig. 6. "Geochemical passports" of native gold types. $\Delta$-standard deviation in element contents in native gold (diagram inscriptions show positively indicative admixture elements placed in their significance-decrease order. Poorly indicative admixture elements are given in brackets)

торную роль (как индикаторный признак) играет данный геохимический тип золота в рассматриваемой группе самородного золота.

В высокопробной группе основная масса самородного золота относится к 4-му типу. Умереннонизкопробная-среднепробная группа представлена преимущественно 5-м, 7-м и 4-м геохимическими типами. По показателю (k) типоморфными для этой группы являются 4-й и 5-й типы. Среди них наибольшая доля приходится на 5-й тип. Основу низкопробной и весьма низкопробной групп составляют 5-й и 7-й геохими- ческие типы самородного золота. Максимально распространен 7-й тип, который можно считать для этих групп наиболее характерным. Схожесть типового состава самородного золота весьма низкопробной и низкопробной групп подтверждает правомерность их объединения в одну (низкопробную) генерацию.

Определяющее значение 4-го, 5-го и 7-го геохимических типов самородного золота соответственно для высокопробной, умереннонизкопробной-среднепробной и низкопробной генераций золота, а следовательно, для висмут- 
сульфотеллуридного, сульфидно-сульфоарсенидного и серебро-полисульфидного минеральных типов оруденения позволяет провести оценку различных типов оруденения в формировании россыпей.

Характер распределения геохимических типов самородного золота по россыпным месторождениям и рудопроявлениям отражен в табл. 4.
Для висмут-сульфотеллуридного минерального типа оруденения рудопроявления Фронт типоморфным является золото 1-го, 4-го и 2-го геохимических типов (см. табл. 4). Основную массу составляют золотины 4-го геохимического типа. Это подтверждает определяющую роль 4-го геохимического типа самородного золота для висмут-сульфотеллуридной разновидности руд.

Таблица 3. Распределение геохимических типов самородного золота по разнопробным группам золота, \% Table 3. Distribution of native gold geochemical types by different gold fineness groups, $\%$

\begin{tabular}{|c|c|c|c|c|c|c|c|c|}
\hline & \multicolumn{7}{|c|}{ Геохимический тип самородного золота } & \multirow[b]{2}{*}{$\mathrm{n}_{\mathrm{M}}$} \\
\hline Группа самородного золота & 1-й & 4-й & 2 -й & 5 -й & 7-й & 6-й & 3-й & \\
\hline Высокопробная (850-1000\%) & $\frac{13.6}{2.187}$ & $\frac{54.5}{0.958}$ & $\frac{9.1}{0.482}$ & $\frac{13.6}{-0.873}$ & $\frac{4.5}{-1.956}$ & $\frac{4.5}{-0.211}$ & - & 22 \\
\hline $\begin{array}{l}\text { Умереннонизкопробная- } \\
\text { среднепробная (700-850\%о) }\end{array}$ & - & $\frac{26.9}{0.252}$ & $\frac{5.1}{-0.090}$ & $\underline{34.6}$ & $\begin{array}{r}-28.2 \\
-0.131\end{array}$ & $\frac{3.8}{-0.378}$ & $\begin{array}{l}\frac{1.3}{-0.177} \\
\end{array}$ & 78 \\
\hline $\begin{array}{l}\text { Весьма низкопробная (350- } \\
500 \% \text { ) }\end{array}$ & - & - & $\frac{7.3}{0.265}$ & $\frac{39.0}{0.178}$ & $\frac{48.8}{0.417}$ & $\begin{array}{l}\underline{4.9} \\
-0.140\end{array}$ & - & 41 \\
\hline Низкопробная (500-700%о) & - & $\begin{array}{l}-14.5 \\
-0.363\end{array}$ & $\frac{3.6}{-0.434}$ & $\underline{32.7}$ & $\frac{36.4}{0.123}$ & $\frac{9.1}{0.482}$ & $\frac{3.6}{0.865}$ & 55 \\
\hline$n_{r}$ & 3 & 41 & 12 & 64 & 63 & 10 & 3 & 196 \\
\hline
\end{tabular}

Примечание. Здесь и в табл. 4 над чертой - доля золота данного геохимического типа в группе (объекте), \%. Под чертой - показатель средневзвешенной доли зерен геохимических типов золота в группе (объекте), рассчитанный по формуле $\mathrm{k}=\ln \left[\left(\mathrm{n}_{\mathrm{M}, \mathrm{r}} \cdot \mathrm{N}\right) /\left(\mathrm{n}_{\mathrm{r}} \cdot \mathrm{n}_{\mathrm{M}}\right)\right]$ (Приставко и др., 2003), где $\mathrm{n}_{\mathrm{M}, \mathrm{r}}-$ количество зерен геохимического типа золота в группе (объекте), $\mathrm{N}$ - общее количество проанализированных зерен золота, $\mathrm{n}_{r}$ - количество зерен золота в целом по геохимическим типам, $\mathrm{n}_{\mathrm{M}}$ - то же по группам самородного золота (объектам). Жирной рамкой ограничены клетки таблицы с положительными значениями $\mathrm{k}$, указывающими на высокую индикаторную роль геохимического типа золота в группе самородного золота (объекте). Прочерк - геохимический тип самородного золота не выявлен.

Таблица 4. Распределение геохимических типов самородного золота по объектам, \% Table 4. Distribution of geochemical types of native gold by objects, \%

\begin{tabular}{|c|c|c|c|c|c|c|c|c|}
\hline & \multicolumn{7}{|c|}{ Геохимический тип самородного золота } & \multirow[b]{2}{*}{$\mathrm{n}_{\mathrm{M}}$} \\
\hline Объект & $3-\breve{и}$ & 1-й & 4-й & 5-й & 2 -й & 7-й & 6-й & \\
\hline $\begin{array}{l}\text { Россыпь руч. Плац- } \\
\text { дарм }\end{array}$ & $\frac{13.6}{2.19}$ & $\frac{4.5}{1.09}$ & $\frac{22.7}{0.08}$ & $\frac{40.9}{0.23}$ & - & $\frac{13.6}{-0.70}$ & $\frac{4.5}{-0.76}$ & 22 \\
\hline $\begin{array}{l}\text { Рудопроявление } \\
\text { Фронт }\end{array}$ & - & $\frac{18.2}{2.47}$ & $\frac{54.5}{0.96}$ & $\frac{18.2}{-0.59}$ & $\frac{9.1}{0.4}$ & - & - & 11 \\
\hline $\begin{array}{l}\text { Россыпь руч. Забы- } \\
\text { тый }\end{array}$ & - & - & $\frac{42.9}{0.72}$ & $\frac{14.3}{-0.83}$ & - & $\frac{42.9}{0.44}$ & - & 14 \\
\hline $\begin{array}{l}\text { Рудопроявление } \\
\text { Плацдарм }\end{array}$ & - & - & $\frac{22.2}{0.06}$ & $\frac{55.6}{0.53}$ & - & $\frac{11.1}{-0.91}$ & $\frac{11.1}{0.14}$ & 9 \\
\hline Россыпь руч. Кункуй & - & - & $\frac{23.5}{0.12}$ & $\frac{50.0}{0.43}$ & - & $\frac{26.5}{-0.19}$ & - & 34 \\
\hline $\begin{array}{l}\text { Россыпь руч. 14-я } \\
\text { Верста }\end{array}$ & - & - & $\frac{17.9}{-0.16}$ & $\frac{39.3}{0.18}$ & $\frac{14.3}{0.85}$ & $\begin{aligned} \frac{21.4}{-0.25} & \end{aligned}$ & $\frac{7.1}{-0.31}$ & 28 \\
\hline $\begin{array}{l}\text { Россыпь руч. Берен- } \\
\text { тал }\end{array}$ & - & - & $\frac{7.9}{-0.97}$ & $\frac{18.4}{0.57}$ & $\frac{13.2}{0.77}$ & $\frac{52.6}{0.65}$ & $\frac{7.9}{-0.21}$ & 38 \\
\hline Россыпь р. Мякит & - & - & $\frac{13.8}{-0.42}$ & $\frac{31.0}{-0.05}$ & $\frac{6.9}{0.12}$ & $\frac{44.8}{0.49}$ & $\frac{3.4}{-1.03}$ & 29 \\
\hline $\begin{array}{l}\text { Рудопроявление } \\
\text { Плацдарм, коллювий }\end{array}$ & - & - & $\frac{18.2}{-0.14}$ & $\frac{18.2}{-0.59}$ & - & $\frac{45.5}{0.5}$ & $\frac{18.2}{0.63}$ & 11 \\
\hline $\mathrm{n}_{\mathrm{r}}$ & 3 & 3 & 41 & 64 & 12 & 63 & 10 & 196 \\
\hline
\end{tabular}


Для сульфидно-сульфоарсенидной минеральной разновидности руд на рудопроявлении Плацдарм характерно золото 5-го, 4-го и 6-го геохимических типов, при максимальной распространенности золота - 5-го типа. Присутствующее в небольшом количестве преимущественно весьма низкопробное теллуристо-сурьмянистое золото 7-го геохимического типа не является характерным. Оно составляет основную массу самородного золота в перекрывающих рудные тела элювиально-коллювиальных образованиях. Полученные материалы подтверждают определяющее значение золота 5-го типа для сульфидно-сульфоарсенидной разновидности оруденения. Весьма же низкопробное теллуристо-сурьмянистое золото 7-го геохимического типа можно считать свойственным периферийным частям золото-редкометалльных рудных систем, где существенную роль начинает играть серебряно-полиметаллическая и сурьмяная минерализация (Hart et al., 2002; Hart, 2007), т. е. для серебро-полисульфидного типа оруденения.

Таким образом, определяющее значение 4-го, 5-го и 7-го геохимических типов самородного золота соответственно для висмутсульфотеллуридного, сульфидно-сульфоарсенидного и серебро-полисульфидного минеральных типов оруденения подтверждается на конкретных рудных объектах. На основе данных о распространенности этих типов золота в россыпных месторождениях оценена роль различных разновидностей оруденения в формировании россыпей.

По долевому соотношению геохимических типов самородного золота в россыпях (см. табл. 4) можно констатировать, что основная масса золота в россыпь руч. Плацдарм поступила из сульфидно-сульфоарсенидного минерального типа оруденения при подчиненной роли висмут-сульфотеллуридного и незначительном участии серебро-полисульфидного типов. В формировании россыпных месторождений руч. 14-я Верста, Берентал и р. Мякит, наряду с сульфидно-сульфоарсенидным, для россыпи руч. 14-я Верста существенную, а для россыпей p. Мякит и особенно руч. Берентал ведущую роль играл серебро-полисульфидный тип оруденения. Основным источником золота в россыпи руч. Кункуй являлся сульфидно-сульфоарсенидный тип оруденения при подчиненном участии висмут-сульфотеллуридного, а в россыпи руч. Забытый - висмут-сульфотеллуридный и сереброполисульфидный.

\section{ЗАКЛЮЧЕНИЕ}

Полученные материалы позволили по-новому реконструировать формационную принадлежность коренных источников россыпных месторождений Нижне-Мякитского рудно-россыпного узла, оценить роль их различных типов в формировании конкретных россыпей, установить их количество и местоположение.

Россыпные месторождения Нижне-Мякитского рудно-россыпного узла сформировались за счет многочисленных рудных проявлений, располагавшихся на всем протяжении россыпей и представленных серебро-полисульфидным с низкопробным (350-700\%), сульфидносульфоарсенидным с умереннонизкопробнымсреднепробным (700-850\%) и висмут-сульфотеллуридным с высокопробным (850-1000\%) золотом минеральными типами золото-редкометалльного оруденения.

В формировании россыпных месторождений узла минеральные типы золото-редкометалльного оруденения играли различную роль. Основным коренным источником золота в россыпи руч. Кункуй служил сульфидно-сульфоарсенидный тип оруденения при подчиненном участии серебро-полисульфидного и висмутсульфотеллуридного, в россыпи руч. Плацдарм сульфидно-арсенидный и висмут-сульфотеллуридный при незначительной роли серебро-полисульфидного. В формировании россыпных месторождений руч. 14-я Верста, Берентал и р. Мякит, наряду ссульфидно-сульфоарсенидным, существенную роль играл серебро-полисульфидный тип оруденения. Для россыпей р. Мякит и особенно руч. Берентал он являлся ведущим. В россыпи руч. Забытый преобладает умереннонизкопробная-среднепробная группа золота, характерная для сульфидно-сульфоарсенидной разновидности оруденения, но геохимическая специализация самородного золота и ведущая индикаторная роль висмута в геохимическом составе тяжелой фракции шлихов (Литвиненко, Шилина, 2016) указывают на формирование этой россыпи преимущественно за счет висмутсульфотеллуридного типа оруденения.

В целом по россыпным месторождениям узла золото примерно в равных пропорциях поступило из сульфидно-сульфоарсенидного и сереброполисульфидного минеральных типов золоторедкометалльного оруденения при подчиненной роли висмут-сульфотеллуридного типа. При сложном взаимоотношении различных типов оруденения на площади узла по мере удаления от интрузивного массива отмечается тенденция смены оруденения висмут-сульфотеллуридного типа сульфидно-сульфоарсенидным и далее сереброполисульфидным. Это хорошо согласуется с установленной на золоторудных месторождениях Аляски моделью рудно-магматической системы, связанной с интрузивами гранитоидов - "intrusion-related gold systems..." (Hart et al., 2002; Hart, 2005, 2007).

Выполненные исследования представляют не только научный, но и практический интерес, так как могут быть использованы для уточнения направле- 
ния поисково-оценочных работ на рудное золото не только в Нижне-Мякитском рудно-россыпном узле, но и в других россыпных узлах с аналогичной геологией россыпных месторождений.

\section{ЛИТЕРАТУРА}

Альшевский A. В. Новые данные по минералогии золото-редкометалльного месторождения Чистое (Центрально-Колымский регион, Бурхалинский рудный узел) // Золото северного обрамления Пацифика / II Междунар. горно-геол. форум, посвящ. 110летию со дня рожд. Ю. А. Билибина : тез. докл. горногеол. конф. (Магадан, 3-5 сент. 2011 г.). Магадан : СВКНИИ ДВО РАН, 2011. С. 54-55.

Билибин Ю. А. Основы геологии россыпей. М. ; Л. : ГОНТИ, 1938. $501 \mathrm{c}$

Горячев Н. А., Колесниченко П. П. Граниты и грейзены Мякитского интрузива как пример локальной рудно-магматической системы// Рудно-магматические системы Северо-Востока СССР : сб. науч. тр. / под ред. Н. А. Шило, В. И. Гончарова. Хабаровск : Хабаров. политех. ин-т, 1990. С. 41-53.

Горячев Н. А., Гамянин Г. Н. Золото-висмутовые (золото-редкометалльные) месторождения СевероВостока России: типы и перспективы промышленного освоения // Золоторудные месторождения Востока России : тр. III Всерос. симп. «Золото Сибири и Дальнего Востока: геология, геохимия, технология, экономика, экология» (Улан-Удэ, 21-25 сент. 2004 г.). Магадан : СВНЦ ДВО РАН, 2006. С. 50-61.

Кистеров К. В. Анализ россыпной золотоносности при проведении поисково-оценочных работ на рудное золото на Северо-Востоке СССР : автореф. дис. ... канд. геол.-мин. наук. Л., 1983. 22 с.

Кистеров К. В., Евсеев С. Ю. Способ поиска золоторудных тел : патент РФ 2162615, МКИ G 01 V 11/00. Заявл. 14.04.2000 ; опубл. 27.01.2001. СПб. : Рос. агентство по патентам и товарным знакам, 2001. 7 с.

Костерин A. B. Шлихо-минералогический и шлихогеохимический методы поисков рудных месторождений / отв. ред. И. Н. Говоров; АН СССР; Дальневост. науч. центр.; Дальневост. геол. ин-т. Новосибирск : Наука, 1972. 124 с.

Кузнецов В. М., Лушников Л. А., Степанов В. А. Оценка формационной принадлежности коренных источников по типоморфным особенностям россыпного золота // Колыма. 1990. № 12. С. 6-11.

Кузнецов В. М., Горячев Н. А., Жигалов С. В., Савва $H$. E. Структура и рудоносность Мякит-Хурчанского рудно-россыпного узла // Вестник СВНЦ ДВО РАН. 2011. № 4. C. 37-51.

Литвиненко И. С., Шилина Л. А. Типоморфизм самородного золота золото-редкометалльного рудопроявления Берентал (Северо-Восток России) // Вопросы геологии и комплексного освоения природных ресурсов Восточной Азии / Пятая Всерос. науч. конф. с междунар. участием, 02-04 окт. 2018 г., Благовещенск : сб. докладов в 2-х т. Благовещенск : ИГиП ДВО РАН, 2018. Т. 1. С. 122-125.

Литвиненко И. С., Шилина Л. А. Типоморфизм самородного золота рудопроявления Плацдарм (Северо-Восток России) // Чтения памяти акад. К. В.
Симакова : Материалы докладов Всерос. науч. конф. (Магадан, 22-24 нояб. 2017 г.). Магадан : ИП Жарикова Т. В., 2017. С. 91-93.

Литвиненко И. С., Шилина Л. А. Шлихо-геохимическая специализация россыпных месторождений Нижне-Мякитского россыпного поля (СевероВосток России) как индикатор формационной принадлежности их коренных источников // Геология и минерально-сырьевые ресурсы Северо-Востока России : материалы Всерос. науч.-практ. конф., 6-8 апр. 2016 г. / отв. ред. Л. И. Полуфунтикова. Якутск : Издат. дом СВФУ, 2016. С. 100-104.

Ньюберри Р. Дю., Лейер П. У., Ганз П. Б., Гончаров B. И., Горячев Н. А., Ворошин С. В. Предварительный анализ хронологии мезозойского магматизма, тектоники и оруденения на Северо-Востоке России с учетом датировок ${ }^{40} \mathrm{Ar} /{ }^{39} \mathrm{Ar}$ и данных по рассеянным элементам изверженных и оруденелых пород // Золотое оруденение и гранитоидный магматизм Северной Пацифики : в 2-х т. Т. 1. Геология, геохронология и геохимия : Тр. Всерос. совещ. Магадан, 4-6 сент. 1997 г. Магадан : СВКНИИ ДВО РАН, 2000. С. 181-205.

Палымский Б. Геологические формации СевероВостока России. Saarbrücken, Deutschland : Palmarium Academic Publiscing, 2012. 207 c.

Позднякова Н. Н. Использование типоморфных признаков россыпного золота при прогнозировании и поисках рудных месторождений (на примере россыпей Шахтаминского района Забайкалья и россыпи р. ЧайЮрья Магаданской области). М. : ЦНИГРИ, 2015. 140 с. http://www.geokniga.org/bookfiles/geokniga-ispolzovanietipomorfnyh-priznakov-rossypnogo-zolota.pdf

Приставко В. А., Пляшкевич А. А., Морозова С. Г. Геолого-геохимические типы руд и метасоматитов месторождения Нодди (Южно-Омолонский рудный район) // Геодинамика, магматизм и минерагения континентальных окраин Севера Пацифики : в 3-х т. : Материалы Всерос. совещ., посвящ. 90-летию акад. Н. А. Шило (XII годичное собрание Сев.-Вост. отделения ВМО). Магадан, 3-6 июня 2003 г. Магадан : СВКНИИ ДВО РАН, 2003. Т. 3. С. 136-139.

Пыцкая E. A. Типоморфные признаки самородного золота Верхояно-Чукотской складчатой области; их значение при поисках золотого оруденения : автореф. дис. ... канд. геол.-минер. наук. М., 1994. 22 с.

Савва Н. Е., Парфенов М. И., Комина В. И. Генетическая природа бимодального распределения пробности шлихового золота россыпи руч. Плацдарм (южные отроги Мякитского интрузива) // Геодинамика, магматизм и минерагения континентальных окраин Севера Пацифики. Магадан : СВКНИИ ДВО РАН, 2003. Т. 3. C. 132-135.

Соломенцева Л. А., Литвиненко И. С. Самородное золото россыпей северо-западного фланга МякитХурчанского рудно-россыпного узла (Северо-Восток России) // Такий різний світ мінералогії: зб. матеріалів наукової конференції присвяченій 100-річчю з дня народження академіка Свгена Костянтиновича Лазаренка (м. Київ, 19-20 квітня 2012 р.). Київ : Національний науково-природничий музей НАН України, 2012. C. $143-148$.

Соломенцева Л. А., Литвиненко И. С. Типоморфизм самородного золота золото-редкометалльного 
рудного проявления Фронт (Северо-Восток России) // Вестник СВНЦ ДВО РАН. 2015. № 2. С. 28-39.

Шилина Л. А., Соцкая О. Т. Особенности строения и условия формирования россыпных месторождений золота Нижне-Мякитского рудно-россыпного узла (Северо-Восток России) // Вестник СВНЦ ДВО РАН. 2018. № 4. C. 49-61.

Шило Н. А. Основы учения о россыпях. М. : Наука, $1981.384 \mathrm{c}$.

Шило Н. А. Россыпи Яно-Колымского золотоносного пояса // Тр. СВКНИИ АН СССР. Магадан, 1963. Вып. 6. 484 с.

Шило Н. А., Гончаров В. И., Альшевский А. В., Ворцепнев $B$. $B$. Условия формирования золотого оруденения в структурах Северо-Востока СССР. М.: Наука, 1988. $181 \mathrm{c.}$

Atlas of native gold from placers of Uzbekistan. Composite authors. Tashkent : Yangi asr avlodi, 2007, State Committee of Republic Uzbekistan on Geology and Mineral Resources. 342 p.
Goryachev N. A., Goncharov V. I. Late Mesozoic granitoid magmatism and related gold and tin mineralization of North-East Asia // Resource Geology Special Issue. Tokyo, 1995. No. 18. P. 111-122.

Hart C. J. R. Classifying, distinguishing and exploring for intrusion-related gold systems // The Gangue. 2005. Vol. 87. P. 1-9.

Hart C. J. R., McCoy D. T., Goldfarb R. J., Smith M. R., Roberts P., Hulstein R., Bakke A. A., Bundtzen T. K. Geology, Exploration, and Discovery in the Tintina Gold Province, Alaska and Yukon // Society of Econ. Geol. Spec. Publ. 2002. No. 9. P. 241-274.

Hart C. J. R. Reduced intrusion-related gold systems // Mineral deposits of Canada: A Synthesis of Major Deposit Types, District Metallogeny, the Evolution of Geological Provinces, and Exploration Methods. Geological Association of Canada, Mineral Deposits Division, Special Publication. 2007. No. 5. P. 95-112.

Поступила в редакичю 23.04.2019 2.

Поступила после доработки 21.05.2019 г.

\title{
RECONSTRUCTION OF PLACER HARD ROCK SOURCES IN THE LOWER MYAKIT ORE-PLACER KNOT (Russia's North-East) BASED ON STUDIES OF NATIVE GOLD
}

\begin{abstract}
I. S. Litvinenko, L. A. Shilina
North-East Interdisciplinary Scientific Research Institute n. a. N. A. Shilo, FEB RAS, Magadan

A comprehensive study of typomorphic properties of native gold from heavy concentrate samples resulted in specifying locations and formational status of placer mother lodes in the Lower Myakit ore-placer knot (Upper Kolyma area in the Yana-Kolyma gold province). Mother lode mineral types and their role in the formation of placer site have been determined. Paragenetic assemblages of microinclusions in native gold, sampled from placer deposits, indicate as their lode sources the silver-polysulfide type with low-fineness (350-700\%) gold, sulfide-sulfoarsenide type with lowmiddle-fineness (700-850\%) gold, and bismuth-sulfotelluride type with high-fineness (850-1000\%) gold. Geochemical type shares of native gold served as a basis to assess significance of different mineralization types participating in formation of specific placer deposits. In general, sulfidesulfoarsenide and silver-polysulfide lode sources were almost equally important, whereas bismuthsulfotelluride type was subordinate. Within the mineral district, the ore mineralization zoning is expressed as basically bismuth-sulfotelluride and sulfide-sulfoarsenide mineralization types in the south and the west, and as silver-polysulfide type in the north and the east.
\end{abstract}

Keywords: Russia's North-East, ore-placer knot, placer deposits, mother lodes, gold typomorphism, granulometry, morphology, internal structures, microinclusions, indicators.

\section{REFERENCES}

Al'shevsky, A. V., 2011, New Data on the Mineralogy of the Chistoye Gold-Rare-Metal Deposit (Central Kolyma District, Burkhala Ore Field), Gold of the North Pacific Rim., II International Geology \& Mining Forum Dedicated to Yu. A. Bilibin's $110^{\text {th }}$ Anniversary, Abstracts of the Geology \& Mining Conference (Magadan, September, 3-5), Magadan, NEISRI FEB RAS, 54-55 [In Russian].

Atlas of Native Gold from Placers of Uzbekistan, 2007, Composite Authors, Tashkent, Yangi Asr Avlodi, State Committee of Republic Uzbekistan on Geology and Mineral Resources [In Uzbek].
Bilibin, Yu. A., 1938, Fundamentals of Placer Geology, Moscow - Leningrad, GONTI [In Russian].

Goryachev, N. A.; Gamyanin, G. N., 2006, Au-Bismuth (Au-Rare-Metal) Deposits of Russia's NorthEast: Mineral Types and Industrial Exploration Perspectives, Gold Lodes of East Russia, Proceedings of the $3^{\text {rd }}$ Symposium "Gold Reserves of Siberia and the Far East: Geology, Geochemistry, Technologies, Economics, and Ecology" (Ulan-Ude, September 21-25, 2004), Magadan, NESC FEB RAS, 50-61 [In Russian]. 
Goryachev, N. A.; Goncharov, V. I., 1995, Late Mesozoic Granitoid Magmatism and Related Gold and Tin Mineralization of North-East Asia, Resource Geology Special Issue, Tokyo, 18, 111-122.

Goryachev, N. A.; Kolesnichenko, P. P., 1990, Granites and Greisens of the Myakit Intrusion as an Example of a Local Ore-Magmatic System, Ore-Magmatic Systems of the USSR North-East, Eds. N. A. Shilo, V. I. Goncharov, Khabarovsk, Khabar. Polytechn. Institute, 41-53 [In Russian].

Hart, C. J. R., 2005, Classifying, Distinguishing and Exploring for Intrusion-Related Gold Systems, The Gangue, 87, 1-9.

Hart, C. J. R., 2007, Reduced Intrusion-Related Gold Systems, Mineral Deposits of Canada: A Synthesis of Major Deposit Types, District Metallogeny, the Evolution of Geological Provinces, and Exploration Methods, Geological Association of Canada, Mineral Deposits Division, Special Publication, 5, 95-112.

Hart, C.J.R.;McCoy, D. T.; Goldfarb, R.J.; Smith, M.R.; Roberts, P. ; Hulstein R.; Bakke, A. A.; Bundtzen, T. K., 2002, Geology, Exploration, and Discovery in the Tintina Gold Province, Alaska and Yukon, Society of Econ. Geol. Spec. Publ., 9, 241-274.

Kisterov, K. V., 1983, Analysis of Placer Gold Mineralization in Lode Gold Prospecting in the USSR North-East, Author's Abstract, Diss. ... Cand. Sci. (Geology \& Mineralogy), Leningrad [In Russian].

Kisterov, K. V.; Evseev, S. Yu., 2001, Identification Methodology for Gold Lode Bodies, RF Patent 2162615 , MKI G 01 V 11/00, Submission Date 14.04.2000, Published 27.01.2000, St. Petersburg, Russia's Patent and Trademark Agency of [In Russian].

Kosterin, A. V., 1972, Mineralogy and Geochemistry of Heavy Concentrations as Methods of Lode Searching, Ed. I. N. Govorov; USSR Academy of Sciences, Far East Scientific Center, Far East Geological Institute, Novosibirsk, Nauka [In Russian].

Kuznetsov, V. M.; Goryachev, N. A.; Zhigalov, S. V.; Savva, N. E., 2011, Structural Setting and Ore Minerals of the Myakit-Khurchan Mineral District, Vestnik NESC FEB RAS, 4, 37-51 [In Russian].

Kuznetsov, V. M.; Lushnikov, L. A.; Stepanov, V. A., 1990, Evaluating Mother Lode Formational Character by Placer Gold Typomorphism, Kolyma, 12, 6-11 [In Russian].

Litvinenko, I. S.; Shilina, L. A., 2016, Heavy Concentrations Geochemical Specialization of Placer Deposits of the Lower Myakit Placer Field (North-East of Russia) as the Indicator of Their Morthe Lode Formational Types, Geology and Mineral Resources of North-East Russia Conference Proceedings, April 6-8, 2016, Ed. L. I. Polufuntikova, Yakutsk, SVFU, 100-104 [In Russian].

Litvinenko, I. S.; Shilina, L. A., 2017, Native Gold Typomorphism at the Platsdarm Occurrence (Northeast Russia), Conference Dedicated to the Memory of Academician K. V. Simakov, Magadan, Conference Proceedings, November 22-24, 2017, Magadan, 91-93 [In Russian].

Litvinenko, I. S.; Shilina, L. A., 2018, Typomorphism of Native Gold from the Berental Au-Rare-Metal Occurrence (North-East of Russia), Geology and Interdisciplinary Development of Natural Resources in East Asia, $5^{\text {th }}$ All-Russia Conference with International Participation, October 2-4, Proceedings in 2 Volumes, Blagoveshchensk, IGiP FEB RAS, 1, 122-125 [In Russian].

Newberry, R. J.; Layer, P. W.; Gans, P. B.; Goncharov, V. I.; Goryachev, N. A.; Voroshin, S. V., 2000, Tentative
Chronology of Mesozoic Magmatism, Tectonics and Mineralization in the North-East of Russia Based on ${ }^{40} \mathrm{Ar} /{ }^{39} \mathrm{Ar}$ Data and Disseminated Elements in Igneous Rocks and Ores, Gold Mineralization and Granitoid Magmatism of North Pacific, Proceedings of the AllRussia Meeting, Magadan, September 4-6, 1997, Vol. 1, Geology, Geochronology and Geochemistry, Magadan, NEISRI FEB RAS, 181-205 [In Russian].

Palymsky, B., 2012, Geological Formations in the North-East of Russia, Saarbrücken, Deutschland, Palmarium Academic Publishing [In Russian].

Pozdnyakova, N. N., 2015, Using Placer Gold Typomorphism to Predict and Search for Lode Deposits (Exemplified by Placer Deposits in the Shaktaminsky District of Transbaikalia and the Chai-Yurya Placer in Magadan Oblast), Moscow, ZNIGRI, http://www.geokniga.org/ bookfiles/geokniga-ispolzovanie-tipomorfnyh-priznakov-rossypnogo-zolota.pdf [In Russian].

Pristavko, V. A.; Plyashkevich, A. A.; Morozova, S. G., 2003, Geological and Geochemical Types of Ores and Metasomatic Rocks of the Noddi Deposit (South Omolon Mineral Area), Geodynamics, Magmatism and Mineralogeny of Continental Margins of the North Pacific; Materials of the All-Russia Conference Dedicated to the $90^{\text {th }}$ Anniversary of Academician N. A. Shilo in 3 Volumes, Magadan, June 3-6, 2003, Magadan, NEISRI FEB RAS, 3, 136-139 [In Russian].

Pytskaya, E. A., 1994, Typomorphic Characteristics of Native Gold in the Verkhoyansk-Chukotka Folded Area and Their Exploration Significance, Author's Abstract, Diss. ... Cand. Sci. (Geology \& Mineralogy), Moscow [In Russian].

Savva, N. E.; Parfenov, M. I.; Komina, V. I., 2003, Genetic Character of Gold Fineness Bimodal Distribution in Heavy Concentration Gold from the Platsdarm Creek Placer (Southern Spurs of the Myakit Intrusive), Geodynamics, Magmatism, and Mineralogeny of Continental Margins of the North Pacific, Magadan, NEISRI FEB RAS, 3, 132-135 [In Russian].

Shilina, L. A.; Sotskaya, O. T., 2018, Structure Features and Formational Environments of Gold Placers at the Nizhny-Myakit Ore-Placer Knot (North-East of Russia), Bulletin of the North-East Science Center, 4, 49-61 [In Russian].

Shilo, N. A., 1963, Placers of the Yana-Kolyma GoldBearing Belt, Proceedings of NEISRI SB AS USSR, 6, Magadan, NEISRI SB AS USSR, 1-484 [In Russian].

Shilo, N. A., 1981, Fundamentals of Placer Deposits, Moskow, Nauka [In Russian].

Shilo, N. A.; Goncharov, V. I.; Al'shevsky, A. V.; Vortsepnyov, V. V., 1988, Conditions of Gold Mineralization in the Structures of the USSR North-East, Moskow, Nauka [In Russian].

Solomentseva, L. A.; Litvinenko, I. S., 2012, Native Placer Gold in the Northwestern Flank of the MyakitKhurchan Ore-Placer Knot (North-East of Russia), Such a Different World of Mineralogy: Materials of the Scientific Conference Dedicated to the $100^{\text {th }}$ Anniversary of Academician Yevhen Konstantinovich Lazarenko (Kyiv, April 19-20, 2012), Kyiv, National Museum of Natural Sciences, NAS of Ukraine, 143-148 [In Ukrainian].

Solomentseva, L. A.; Litvinenko, I. S., 2015, Native Gold Typomorphism of the Front Au-Rare-Metal Ore Occurrence (North-East of Russia), Vestnik NESC FEB RAS, 2, 28-39 [In Russian]. 